\title{
Future Priorities for Development Informatics Research from the Post-2015 Development Agenda
}

Link to publication record in Manchester Research Explorer

\section{Citation for published version (APA):}

Heeks, R. (2014). Future Priorities for Development Informatics Research from the Post-2015 Development Agenda. (IDPM Development Informatics Working Papers; No. 57).

http://www.seed.manchester.ac.uk/subjects/idpm/research/publications/wp/di/di-wp57/

\section{Citing this paper}

Please note that where the full-text provided on Manchester Research Explorer is the Author Accepted Manuscript or Proof version this may differ from the final Published version. If citing, it is advised that you check and use the publisher's definitive version.

\section{General rights}

Copyright and moral rights for the publications made accessible in the Research Explorer are retained by the authors and/or other copyright owners and it is a condition of accessing publications that users recognise and abide by the legal requirements associated with these rights.

\section{Takedown policy}

If you believe that this document breaches copyright please refer to the University of Manchester's Takedown Procedures [http://man.ac.uk/04Y6Bo] or contact uml.scholarlycommunications@manchester.ac.uk providing relevant details, so we can investigate your claim.

\section{OPEN ACCESS}




\title{
Development Informatics
}

\section{Working Paper Series}

The Development Informatics working paper series discusses the broad issues surrounding information, knowledge, information systems, and information and communication technologies in the process of socio-economic development

Paper No. 57

\section{Future Priorities for Development Informatics Research from the Post-2015 Development Agenda}

\author{
RICHARD HEEKS
}

2014

ISBN: 978-1-905469-84-0

Published Centre for Development Informatics

by: $\quad$ Institute for Development Policy and Management, SEED

University of Manchester, Arthur Lewis Building, Manchester, M13 9PL, UK

Email: cdi@manchester.ac.uk Web: http://www.cdi.manchester.ac.uk

View/Download from:

http://www.seed.manchester.ac.uk/subjects/idpm/research/publications/wp/di/

Educators' Guide from:

http://www.seed.manchester.ac.uk/subjects/idpm/research/publications/wp/di/educdi/ 


\section{Table of Contents}

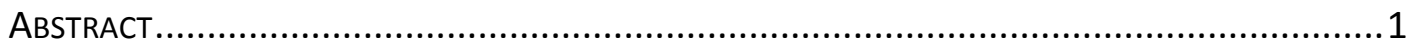

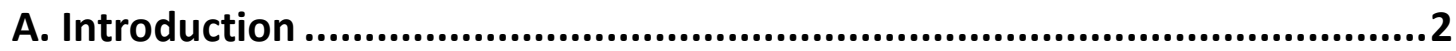

B. Analysis of Current Development Informatics Research ........................4

C. Post-2015 Development Informatics Research Priorities .........................8

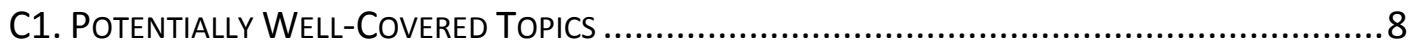

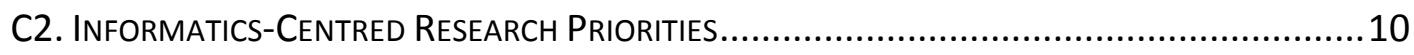

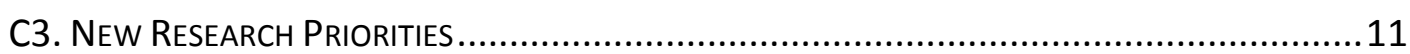

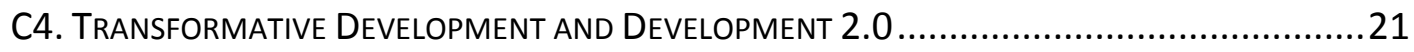

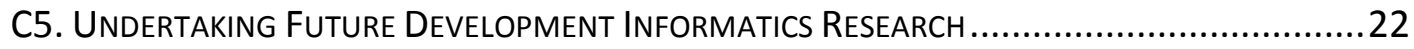

D. The Past and Future of Development Informatics Research ..................24

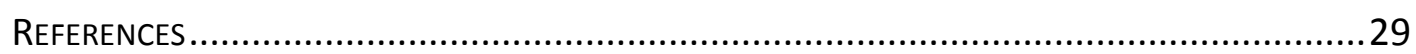

Appendix A: Most Frequently-Appearing Terms in Current DeVelopment Informatics

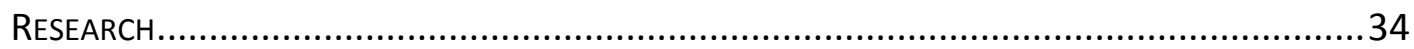

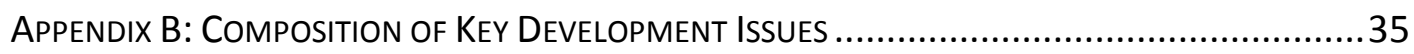

Appendix C: Differences Between Post-2015 and CuRRent DeVelopment Informatics

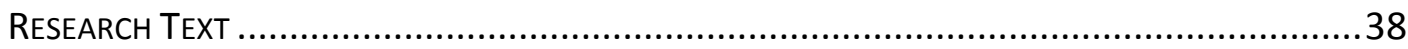

APPENDIX D: DEVELOPMENT INFORMATICS JOURNAL START DATES .....................................44 


\title{
Future Priorities for Development Informatics Research from the Post-2015 Development Agenda
}

\author{
Richard Heeks \\ Centre for Development Informatics \\ IDPM, University of Manchester, UK \\ Email: richard.heeks@manchester.ac.uk
}

2014

\begin{abstract}
At the end of 2015, the Millennium Development Goals will be replaced by the post-2015 development agenda (PTDA). The foundational content is in place for this new agenda, which will be the single most-important force shaping the future of international development. In planning our priorities for development informatics research - the academic study of ICT4D policy and practice - we should therefore pay close attention to the PTDA.

This paper undertakes a comparative analysis of the post-2015 development agenda versus the current content of development informatics (DI) research. From this analysis, it identifies a set of post-2015 priorities in international development which have to date been under-emphasised within development informatics. In all, 16 development informatics research gaps for a post-2015 world are identified. The research agenda for each gap is described alongside the more general need for DI research to break out of the "ICT4D bubble" and engage more with the development mainstream.

Those gaps, plus other key topics, are used to create a map of post-2015 development informatics research priorities; a map which will be of significant value to academic and other researchers planning their future DI activities. The paper ends by contemplating what the key narrative will be for the coming "fifth wave" of development informatics research: sustainable informatics, inclusive informatics, or Development 2.0.
\end{abstract}




\section{A. Introduction}

If we shape our research priorities based on the context of broader trends, what trends should we attend to in development informatics research?

Development informatics - the academic sub-discipline that studies the role of information and communication technologies in international development (ICT4D) - represents the intersection of two main disciplines: development studies, and informatics; the latter itself representing a continuum from computer science through human-computer interaction to information systems (see Figure 1).

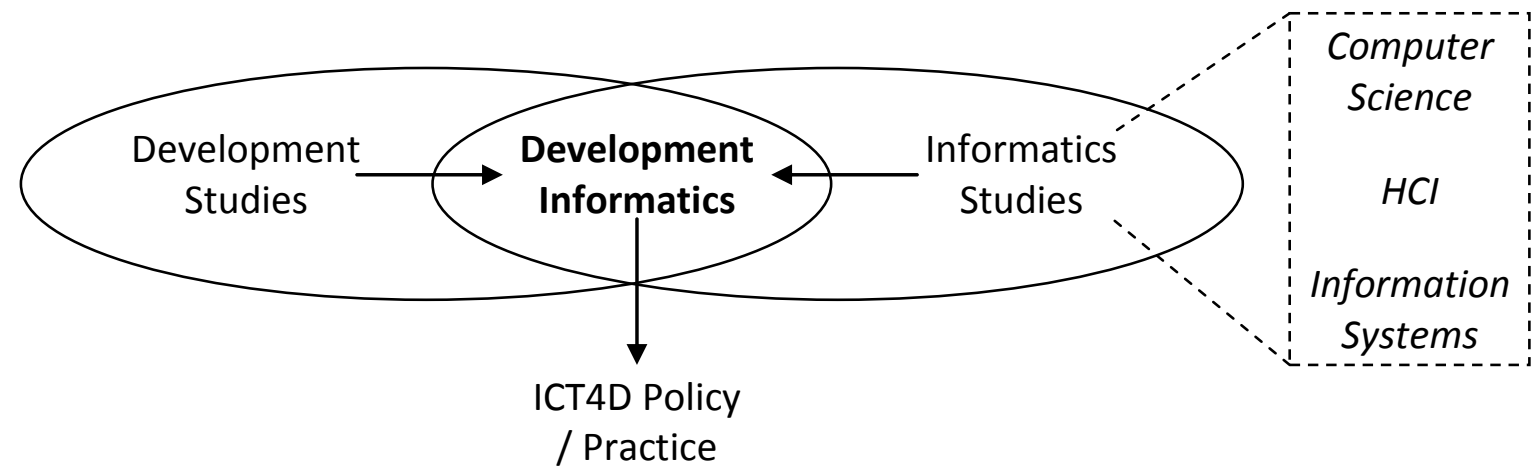

Figure 1: Disciplinary Foundations for Development Informatics

So, if we want to understand future directions in development informatics research, we can be guided by trends both in development and in informatics. Though returning to this briefly later, I will not discuss informatics trends in detail. Some obvious contenders would be: near-ubiquity of mobile, more big/open/real-time data, use of field sensors/embedded computing, more social media, more crowd-sourcing models, more cloud, more smartphones, and 3D printing.

Instead, this paper focuses on the development side of the equation, looking for the major trends in ideas and priorities within international development. One can argue that the Millennium Development Goals (MDGs) have been a key force shaping the international development agenda since the early 2000s. It follows that the same may be true for the "post-2015 development agenda" (PTDA) which succeeds the MDGs from the end of 2015. Box 1 summarises evidence on this and suggests the value of using the post-2015 agenda to shape our research.

Given the time lags in planning, implementing and disseminating research, it is opportune to investigate the post-2015 agenda, and its implications for development informatics research priorities.

Why do this? There are three reasons:

- Money: if the post-2015 agenda shapes the priorities of research funders, then we are more likely to get funding for research that meshes with this agenda. 
- Outcome: our research must be original, rigorous and significant ${ }^{1}$. Rigour is internally determined but originality and significance are externally-determined perceptions, both of which encourage us to find the "fast currents" in our research domain, and leap into them. Put simply, if our research fits into a new and fast-growing or large-scale trend in thinking, it has a greater likelihood of being read and used by other researchers ${ }^{2}$, and of being read and used by practitioners.

- Impact: if the post-2015 agenda reflects what matters and what works in delivering socio-economic development, then there can be no better guide for prioritising research that makes a difference, and that has a real-world impact.

If our future development informatics research is in synch with post-2015, at the least we can use that to boost the credibility and perceived relevance of our research; at the most, we will gain greater funding and a wider audience and more impact for our research.

\section{Box 1: How Important Will the Post-2015 Agenda Be?}

Elsewhere (Heeks 2014), I present evidence to answer two questions.

Q1: "How important will the PTDA be to international development?". Tens of thousands of development organisations worldwide have so far engaged in consultations on the post-2015 agenda. The nearest historical correlate of that agenda - the MDGs - have had a somewhat limited impact on development outcomes and practice, but a greater impact on policy, levels of aid and, particularly, development discourse and debate.

Q2: "How important will the PTDA be to development research agendas and funding?". The leading development research institutes outside the US all have post-2015 programmes or initiatives underway. The MDGs had a varying impact on the priorities of development research funders from peripheral through moderate to extensive.

"Taking together all of the evidence, it seems reasonable to conclude that whatever its absolute strength and with acknowledgement to local variations - the post-2015 development agenda will be the single most important force shaping the future of development and of development research." (ibid.: 9)

In a previous paper (Heeks 2014), I analysed both the static content of the post-2015 agenda, and also made a dynamic comparison with the MDGs. Table 1 shows the twentyfive key development issues - divided into goals, mechanisms and perspectives - which emerged from the comparative analysis. It uses a four-way categorisation to indicate whether they are falling down, continuing on, rising somewhat, or rising sharply up the international development agenda.

\footnotetext{
${ }^{1}$ The three criteria used by the UK's Research Assessment Exercise and then Research Excellence Framework.

${ }^{2}$ Writing something at the start of a growing trend on average generates more citations than writing something in a mature field (Heeks 2010b).
} 


\begin{tabular}{|c|c|c|c|}
\hline $\begin{array}{l}\text { MDG to PTDA } \\
\text { Change }\end{array}$ & Development Goals & \begin{tabular}{|l|} 
Development \\
Mechanisms \\
\end{tabular} & \begin{tabular}{|l|} 
Development \\
Perspectives \\
\end{tabular} \\
\hline Diminution & $\begin{array}{l}\text { - MDG } 8 \text { with ICTs/Digital } \\
\text { - Manufacturing } \\
\text { - Insecurity }\end{array}$ & $\begin{array}{l}\text { - Traditional Development } \\
\text { Finance } \\
\text { - Development Strategy }\end{array}$ & \\
\hline Continuity & $\begin{array}{l}\text { - Wellbeing } \\
\text { - Infrastructure } \\
\text { - Urban Development } \\
\text { - Institutional } \\
\text { Development } \\
\text { - MDGs 1-6 }\end{array}$ & - Informatics & \\
\hline Some Expansion & $\begin{array}{l}\text { - Rural/Agricultural } \\
\text { Development } \\
\text { - Services } \\
\text { - Livelihoods } \\
\text { - Growth and Jobs } \\
\text { - Rights and Justice }\end{array}$ & $\begin{array}{l}\text { - New Development } \\
\text { Finance } \\
\text { - Technovation inc. Data } \\
\text { and Mobile }\end{array}$ & $\begin{array}{l}\text { - Complex Adaptive } \\
\text { Systems }\end{array}$ \\
\hline $\begin{array}{l}\text { Significant } \\
\text { Expansion }\end{array}$ & $\begin{array}{l}\text { - Open Development } \\
\text { - Inclusive Development } \\
\text { - Migration } \\
\text { - Environment and } \\
\text { Sustainability }\end{array}$ & $\begin{array}{l}\text { - Development Projects } \\
\text { - New Stakeholders }\end{array}$ & \\
\hline
\end{tabular}

Table 1: Summarising Changes in Development Issues from MDGs to Post-2015 Agenda

Readers who would like further detail about these issues may refer to that earlier paper. In this paper, the focus will be on comparing the emerging post-2015 development priorities with the current state of development informatics research. Section B explains how this comparison was undertaken. Section $C$ examines implications for development informatics research priorities, and identifies 16 research gaps that need to be filled. Section D develops an overall map of research priorities, and draws final conclusions based on a model of five waves of development informatics research.

\section{B. Analysis of Current Development Informatics Research}

Given the importance of the post-2015 development agenda then, for the reasons given above, it will make sense for our development informatics (DI) research directions to be shaped by that agenda. To analyse where research gaps and priorities lie within the field of development informatics, we thus need to compare the current state of DI research with the content of the emerging PTDA.

There are a number of ways in which this could be done. Here, the focus is a comparison of text content between two sets of documentation. First, current development informatics research. This was collated from 116 papers presented during 2013 in three key DI research outlets: 
- 16 papers published in the 2013 issues of the journal, Information Technologies and International Development ${ }^{3}$.

- 73 papers presented at the May 2013 IFIP WG9.4 12th International Conference on Social Implications of Computers in Developing Countries, held in Ocho Rios, Jamaica.

- 27 papers presented at the December 2013 ICTD2013 international conference, held in Cape Town ${ }^{4}$.

Second, the four key documents that provide the foundation to date for the post-2015 process:

- The initial "Realizing the Future We Want for All" document (UN 2012) and its update "A Renewed Global Partnership for Development" (UN 2013): these are the products in 2012 and 2013 respectively of the UN System Task Team; the core of the post-2015 process.

- The report, "A New Global Partnership" (HLP 2013) which was produced in mid-2013 by a High-Level Panel set up by UN General Secretary Ban Ki-moon. This report has been strongly associated with post-2015 discussions.

- The Open Working Group, and High-Level Political Forum, and Expert Committee associated with Rio+20 and the Sustainable Development Goals form a second track of PTDA activities. At the time of writing, they are all in mid-process, so the best guide as yet is the outcome of the Rio+20 conference which is a UN General Assembly resolution of 2012 entitled, "The Future We Want" (UNGA 2012).

Each set of documents was combined into a single overall document, and then textual analysis was undertaken via comparative word counts, with details provided in Box 2 .

\section{Box 2: Comparative Textual Analysis of DI vs. PTDA Documentation}

The process began with identification of roughly 200 terms that provided a specific and meaningful sense of direction within the international development agenda. As explained in Heeks $(2014)^{5}$, the term list was developed via selection from the top 500 words counted in the combined post-2015 documentation using Wordle; eliminating all non-discriminatory terms (very simple words like 'and', 'the', 'of'; basic words like 'also', 'must', 'well'; and those which relate to development but do not provide any particular guide to a development agenda such as 'development', 'developing', 'countries', etc). This list was then cross-checked and modified with a similar selection of top 500 terms from documentation relating to the Millennium Development Goals, and with terms used in a set of other current development reports and journal paper titles including those published in the top three development studies journals during 2013.

The list of the most frequently-appearing of those terms in the development informatics research papers is provided in Appendix A.

\footnotetext{
${ }^{3}$ By some measures, the leading development informatics journal (Heeks 2010c).

${ }^{4}$ Together, the IFIP WG9.4 and ICTD series of conferences are the two leading academic gatherings in the field of development informatics, with WG9.4 holding regular conferences since the first in 1988 (http://www.ifipwg94.org/) and ICTD holding regular conferences since 2006 (http://ictdconference.org/).

${ }^{5}$ Some of the text that follows is repeated, with minor variations, from this earlier source.
} 
In order to allow for comparability, the frequency of all terms was normed to a mean count per 10,000 words. The frequency of those terms within the DI documents and within the PTDA documents was then compared, calculating the percentage change in frequency per 10,000 words, and the absolute change in frequency per 10,000 words. Since these two measures represent different but important aspects of change, some overall measure was needed: an average of the two. That overall measure was created by using a comparable indicator - standard deviation - and calculating the average variation from zero of each term on the basis of that indicator ${ }^{6}$. Given the large number of terms used, some of them were aggregated into the set of 25 "development issues" shown in Table 1. The basis for that aggregation is shown in Appendix B.

There are challenges in undertaking this comparison. The two sets of documents draw from different disciplinary "languages": the PTDA documents largely from development studies; the development informatics documents slightly from development studies but more from information systems and computer science. Terms may thus have different prevalence because they have different meanings, with the DI documents often having additional meanings - e.g. 'rights' meaning both human rights and computer access rights; 'security' meaning both human and cybersecurity. The two sets of documents are also different in style: the former being policy documents for broad consumption; the latter being academic documents including citations and references. This again means terms may have different prevalence due to different meanings: in the DI document, 'employ*' includes not only employment as a development issue but also descriptions of how the researchers employed particular techniques; the word 'psychology' did not appear in the PTDA documents and it does in the DI documents but often in the name of a cited journal; there is little mention of 'universit*' in the PTDA documents but it is highly prevalent in the DI documents with their many academic author affiliations.

However, these caveats all tend in one direction: to overstate the prevalence of terms in development informatics relative to the PTDA. This might therefore obscure research gaps, making it appear that a topic is more covered in current DI research than it really is. Account was taken of this by attending not just to bare numbers around aggregated development issues but drilling down to look at individual terms and at the meanings of those terms in context within the research papers. Additionally, these challenges should not interfere with the key interest gaps that do appear, reflecting under-representation of issues in current development informatics research. Care must still be taken with gaps because what one might call the "developmental-richness" of language in the DI papers is likely to be lower than for the UN documentation. Therefore one would anticipate many issues to appear under-represented, and attention thus was paid more to relative levels of under-representation. An individual "manual" analysis was also undertaken

\footnotetext{
${ }^{6}$ Standard deviation is an imperfect indicator for the datasets but since it is not the absolute figure that was important in the calculation, but just some standardised and comparable measure of data dispersion, it serves as an adequate indicator.
} 
of the specific subject area of the 116 papers, and this is also incorporated into the prioritisation and discussion below.

In all this is an imperfect process but attempts have been made to address the imperfections, and there is some reasonable claim to rigour and validity.

What did the comparison of DI research and the post-2015 agenda show? Appendix C shows the foundational data for the exercise at the level of individual terms, and also at the level of aggregated development issues (as a reminder, see Appendix B for the construction of those issues). Figure 2 plots the research gap measure: the extent of difference between the post-2015 discourse and the content of current development informatics research papers ${ }^{7}$. Issues above the line are more highly represented in DI documents than in the post-2015 agenda; issues below the line are less highly represented. The larger the indicator the greater the over- or under-representation.

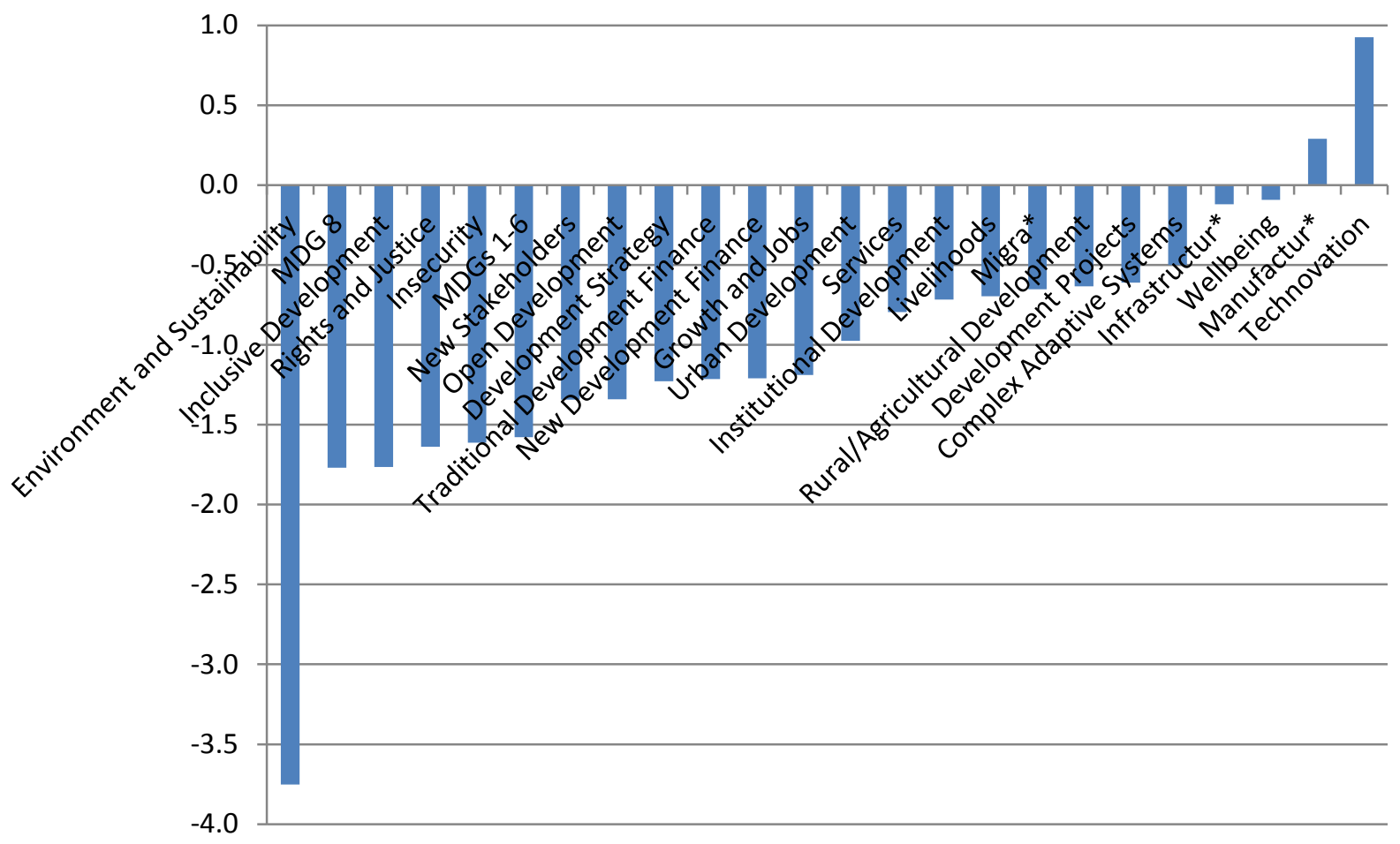

Figure 2: Measure of "Research Gap" Between Development Informatics Research and Post-2015 Agenda

\footnotetext{
7 "Informatics" has been removed from this chart and its calculations because it is axiomatic that this appears far more often - roughly six times more frequently - in the DI papers than in the PTDA documents.
} 


\section{Post-2015 Development Informatics Research Priorities}

The data presented in Appendix C, including the summary shown in Figure 2, provide the basis for identifying future priorities for development informatics research. That analysis is undertaken below, looking first at topics which show as over-represented in current DI research; both development topics and then informatics topics. Next - and the main focus of this section - is to look at under-represented topics plus other data from analysis of DI papers (see details in Box 2) and also from analysis of the post-2015 agenda content and trends (see Section A and Heeks 2014). Together these are used to produce a list of research topics that should be given greater priority. Section $C$ ends with discussion of what could be an over-arching research gap - "Development 2.0" - and some brief thoughts about how future DI research should be undertaken.

\section{C1. Potentially Well-Covered Topics}

Not a great deal can be concluded from those aggregated items which appear "above the line" or very close to zero. 'Technovation' is there due to the mentions of 'technology' - to be expected since it is a part of 'information and communication technology' - but innovation remains something of a research gap. Occurrences of items within 'manufacturing' and 'wellbeing' are too few or potentially skewed (see comments in Box 2).

Some of the individual above-the-line items that appear at the bottom of Table C1 similarly may not tell us very much. For example:

- 'Ethics'/'morality' appears a lot due to two papers specifically on this topic; similarly 'emotion' appears many times in a paper about use of ICTs by migrant workers. The same is true of 'humanitarian' and of 'war'; that their frequency is raised by multiple discussion in one paper. But all these terms appear less than a handful of times in the post-2015 documents.

- 'Female' and 'woman' and 'compet*' similarly appear barely at all in the post-2015 documents, so it is easy for relatively limited discussion in academic research to appear to over-represent by comparison.

Other items may tell a little more about the state of development informatics research, even though they do not appear that often in the PTDA:

- Evaluation has been a particular concern research on ICT4D projects (see Heeks \& Molla 2009).

- NGOs have relatively often been research and/or implementation partners for ICT4D projects - more so than government and the private sector which, anecdotally, are seen as harder to work with. Of course this may not be the same as researching the use of ICTs within NGOs.

- Development informatics research has always had a concern for the impact of context, and discussion of culture is often part of this contextualisation.

- Enterprise and entrepreneurs: there has been a small but continuous strand of work looking at ICTs in small and micro-enterprise (four of the 116 papers fall into this category). 
- Learning: e-learning is relatively well-researched within the development informatics field, having a specific journal - the International Journal of Education and Development Using Information and Communication Technology - and with 6 of the 116 papers on this topic area. However, as noted in Table C1, 'education' shows as under-represented, which counter-balances somewhat.

- The notion of complexity appears many times throughout the corpus of development informatics research. Only relatively rarely is this related explicitly to ideas of complexity theory or complex adaptive systems; more, it seems to just be part of the worldview - or at least language - of DI researchers; that they characterise the issues, models and systems they investigate as complex.

- Infrastructure: as an overall topic, this appears roughly at parity, perhaps expectedly, given the interest of DI research in telecommunications (an over-represented term) infrastructure.

- Discussion of 'citizens' was not that widespread in the post-2015 agenda, but a small number of papers on $\mathrm{G} 2 \mathrm{C}$ e-government systems necessarily use the term repeatedly.

Most convincing are:

- Capabilities: there has been quite a concerted focus on the relationship between ICTs and capabilities with a number of research papers and journal special issues and books published on this (e.g. Andersson et al 2012, Kleine 2013). It is thus hard to argue that this is a topic requiring additional focus.

- Health: likewise the use of ICTs in healthcare in development has been a particular focus for development informatics work, supported particularly by researchers from the University of Oslo who typically ensure a significant presence for this at IFIP WG9.4 conferences. But there is an almost proportional presence in ICTD conferences so that, overall, $22 \%$ of the papers sampled -26 of the 116 - are specifically about healthcare applications of ICTs. Like capabilities, this therefore appears to be a fairly well-covered topic. 


\section{C2. Informatics-Centred Research Priorities}

As noted above, all informatics terms are significantly over-represented in the DI papers compared to the PTDA, as one would expect. However, the relative representation of terms - shown in Figure 3 - may tell us something.

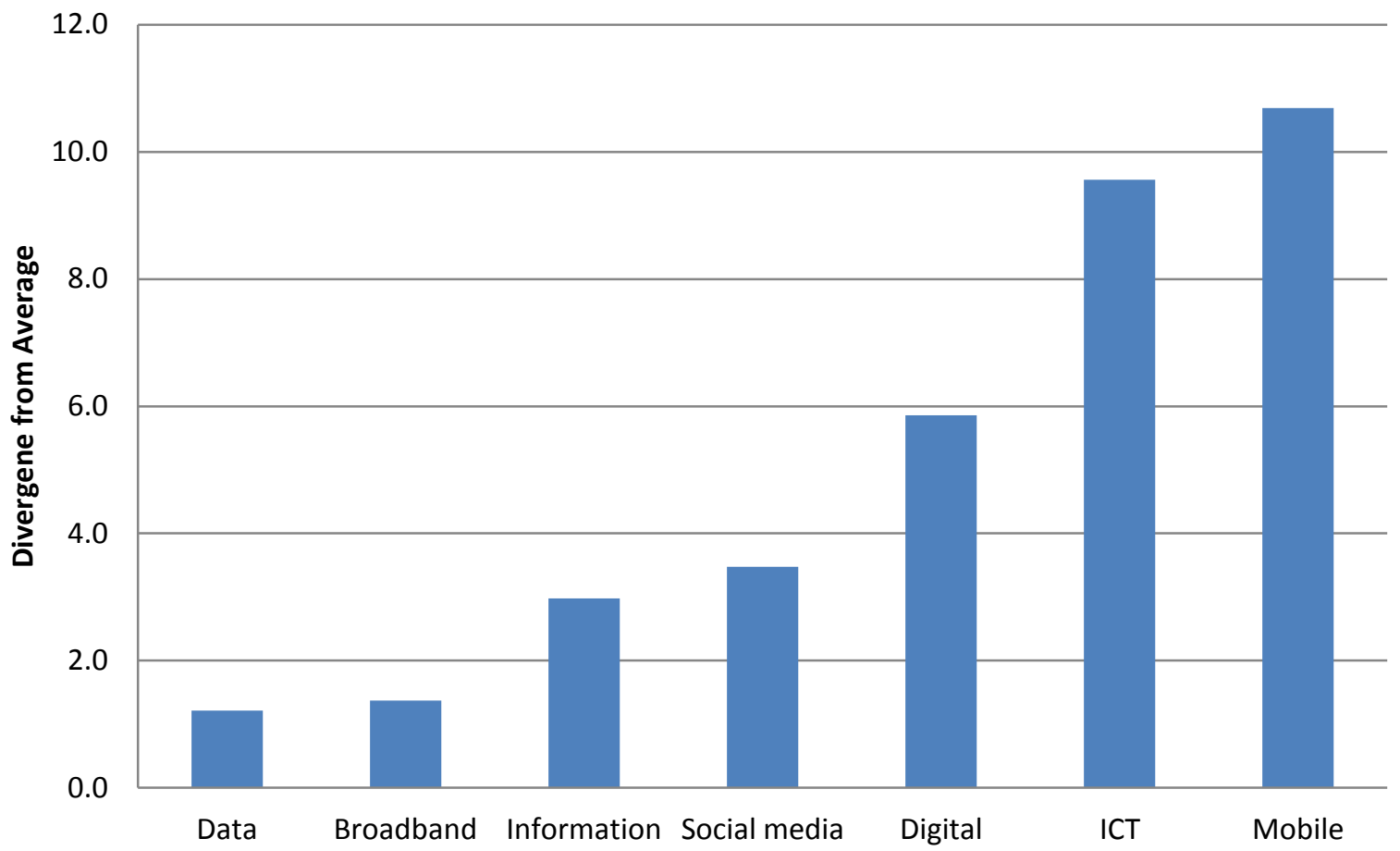

Figure 3: Relative DI vs. PTDA Prevalence of Informatics-Centred Terms

All terms are over-represented and this is a rough-and-ready calculation. However, we can draw a couple of conclusions. Mobile appears to be fairly well covered as a research topic with just under one-quarter of the reviewed DI papers being specifically about mobile, and many more including some discussion about mobiles in development ${ }^{8}$.

The opposite is true of data and broadband, with no papers specifically on either topic. Given how often data is mentioned in the PTDA, it warrants inclusion as a post-2015-related new research priority (see next section). Broadband is only mentioned once in the PTDA and like many emerging ICTs in development that are not mentioned at all - cloud, 4G, smartphones, sensors, 3D printing, etc - one would both recommend and expect to see these form a greater part of the future development informatics research agenda.

\footnotetext{
${ }^{8}$ Though the distribution was skewed: only just over one tenth of the IFIP WG9.4 papers were focused on mobile, whereas around one-third in the other two outlets were.
} 


\section{C3. New Research Priorities}

What of under-represented items? As can be seen from Appendices B and C, the aggregated development issues sometimes bring together elements with very different stories, and therefore Tables $\mathrm{C} 1$ and $\mathrm{C} 2$ are used together in what follows. As noted in Box 2 , these were not simply taken at face value but were read in relative as much as absolute terms, and were also read in context within the papers. Additional data for the creation of the research priorities that follows came from two sources. First, from individual analysis of the topic areas of the DI papers reviewed. Second, from both a static analysis of content of the post-2015 agenda (reported in Heeks 2014) and, especially, a dynamic analysis of trends in the post-2015 agenda (ibid.), a summary of which was presented in Table 1.

The result of this combined analysis produces the "fifteen for post-2015" largest development informatics research gaps, in descending priority order, shown in Table 2. As discussed below, "Development 2.0" will also find a place here once clarified to make "sixteen for 2016 onwards", and is shown where it should appear in priority terms but without being numbered.

\section{Environment and Sustainability \\ 2. Poverty \\ 3. Development Management \\ 4. Food and Agriculture \\ 5. Development Finance \\ 6. Inclusive Development \\ 7. Rights and Justice \\ 8. Data Revolution \\ Development 2.0 \\ 9. Growth and Jobs \\ 10. Security and Violence \\ 11. Gender/Women \\ 12. Cross-Border Flows \\ 13. Resilience \\ 14. Governance \\ 15. Urban Development}

Table 2: Top Post-2015 Development Informatics Research Gap Priorities

The argument here is not that no research exists in these areas; but that these represent the greatest differences between the priority accorded to a topic in the post-2015 agenda and the presence of that topic within development informatics research. Each one would of course require extensive reading of current materials in both the development and development informatics spheres in order to accurately locate the future research agenda. There is only space here to give a brief discussion, and this should be read in conjunction with the discussion of the role of these issues on the development agenda in Heeks (ibid.).

1. Environment and Sustainability: sustainability represents a very strong theme throughout the post-2015 agenda. It forms by far the greatest individual research gap because so little development informatics research is currently undertaken within this 
domain: only two of the 116 papers address sustainability, and none address climate change or other environmental issues.

In this domain, an overall research programme is needed to understand the connections between the sustainable development paradigm and informatics in general terms; and the more specific connections between environment and informatics. A major element of this will be the link between ICTs and climate change where the research agenda can be divided into (Ospina \& Heeks 2012) ${ }^{9}$ :

- Adaptation: the climate change priority for developing countries, with a need to better fit ICTs to current adaptational plans and actions.

- Mitigation: including green IT and smart applications.

- Monitoring: including use of e-participatory methods.

- Strategies: particularly support for climate change policy-making and National Adaptation Programmes of Action.

However there are many other more specific research topics that fall within this overall domain and which require greater attention from those working in development informatics:

- Research to investigate specifically how ICTs can improve energy supply and energy security in developing countries, including greater use of renewable sources.

- Analysis of the links between ICTs and water from modelling and mapping fresh and underground water systems, to reporting mechanisms on water supply points. Similar work is also needed on the role of ICTs in improving sanitation systems.

- Research on ICTs and the components of disaster management: preparation, response, recovery and reconstruction.

- Understanding ICTs' contribution to pollution; for example, research on e-waste.

- Researching how to ensure fewer failures and greater sustainability of ICT4D projects.

- Although accorded its own separate gap (see below), research on ICTs and resilience very much connects to this topic area.

Finally, it is worth just re-stressing the degree to which this represents by far the greatest gap, and priority, for post-2015 development informatics research.

2. Poverty: poverty was central to the MDG agenda and remains central to the post-2015 agenda. Yet it appears far too rarely in development informatics research - in the sample it was discussed around one-tenth as much as health and, of the 116 DI papers analysed, only two directly take poverty as their focus. The limited ability of development informatics research to effectively engage with the issue of poverty - and with the discourse and theories of poverty ${ }^{10}$ - may partly explain why ICTs slipped away from the development mainstream during the 2000s. The combined centrality of environment and poverty to the future development agenda mean ICT may remain somewhat sidelined unless that engagement can be made, speaking to both financial and broader notions of poverty.

\footnotetext{
${ }^{9}$ For further case evidence and foundation/strategy papers on this issue, see: www.niccd.org

${ }^{10}$ Though not exactly a theory of poverty, it is notable that work on livelihoods also appears underrepresented within the development informatics field when compared to the post-2015 agenda.
} 
3. Development Management: post-2015 development seems likely to be more of a process of multi-stakeholder partnerships and cooperative initiatives than previously. ICTS can, of course, facilitate this type of structure and working but there has been a strong tendency for development informatics research to focus on development outcomes rather than development organisations and processes. Where there is a focus on processes, it is on the process of ICT4D far more than looking at how ICT can support broader development processes $^{11}$. There will need to be significantly more research that investigates exactly how digital technologies can best support multi-partner actions: identification of partners, group decision processes both face-to-face and virtual, and distributed but cooperative implementation, among others.

This is a subset of a broader requirement for development informatics research to break out of the "ICT4D bubble" and study how ICTs can support the management of development programmes and projects generally. Specific gaps show up in Table C1 around 'implementation' and 'monitoring' ${ }^{12}$ but the research needs to encompass all stages of the development project/programme lifecycle, looking at how ICTs can facilitate not just traditional forms of development management but also be more transformative; for example to support the lean and agile ideas that are emerging into the development landscape (e.g. Schiffer 2011, Hill 2013).

One final component of this agenda is leadership. Leadership does not have a great presence within the post-2015 agenda though that is in part explained by the many synonyms or alternate phrasings that may be used in its place. But it does emerge as underrepresented in current development informatics research with no papers on this topic in the reviewed selection. The broad sense of individuals such as leaders in development is that they were over-emphasised in early decades (e.g. with "big man" concepts), underemphasised during the decades of domination by structural ideas, and are more recently making some sort of comeback (e.g. Gill et al 2009, Denizer et al 2011). Similarly within development informatics research there has been little recognition of the important role that key individuals like leaders and champions play, with a need for research on issues including: the origins of such individuals, their profile, the actions they take, their relations with others, and their impact on ICT4D projects and other initiatives (Renken \& Heeks 2013). As with other aspects of development management, there will equally need to be work outside the ICT4D bubble looking at how ICTs relate to leadership of generic development initiatives.

4. Food and Agriculture: there is development informatics research being undertaken in this domain; not least - and not surprisingly given the domain title - supported by the FAO (see, e.g. www.e-agriculture.org). Looking at the current papers, there may have been rather a focus on market prices and basic agricultural information, which needs to expand to

\footnotetext{
${ }^{11}$ As an example, two of the 116 reviewed papers relate to partnerships, but they research collaborative activity within ICT4D projects. They do not look at the way in which ICT can support development partnerships generally. Similarly, investigation of 'collab*' and 'particip*' - flagged as over-represented - shows their occurrence relates to these issues within ICT4D, not within development processes generally.

${ }^{12}$ Gaps are much smaller for 'management' and 'process*' but it is marked that they exist at all given the extent to which development informatics draws in part from management literature ideas and language.
} 
encompass the broad future remit for this development domain. This will include further research on using ICTs:

- to improve agricultural productivity and sustainable incomes;

- to manage and improve agricultural supply chains;

- to address food security, malnutrition and hunger.

- to address an issue at the intersection of this topic and others - land - relating ICTs to land degradation, land management, and land rights and tenure.

5. Development Finance: new and traditional development finance register almost equally as research gaps in development informatics (see Table C2). Looking in more detail, finance itself is quite seriously under-represented and then a whole slew of finance-related topics register relative under-representation (see Table C1): investment, debt, aid/ODA, philanthropy, tax and remittances. This has arisen because the main engagement development informatics research has had with financial topics has been around use of mobiles for $\mathrm{m}$-money and $\mathrm{m}$-banking ${ }^{13}$. There thus remains a whole set of finance informatics topics that require further research. These can be derived from the text analysis: e-remittances (though covered to some extent already due to remittance being a core use of mobile money transfer); use of ICTs to improve tax systems and also taxation of ICTs (the mobile sector forming a core and growing tax base for many developing countries); use of ICTs to manage and monitor aid flows and debt; ICT-enabled investment channels and investment in ICTs. Alongside this there are more general research agendas relating to finance, informatics and development at macro, meso and micro levels, including the need for new evidence, new conceptualisations, and new methodologies (Duncombe \& Boateng 2009).

6. Inclusive Development: while this certainly relates to the issues of rights and justice, discussed next, inclusive development may take a rather more instrumental approach; for example, in its concern about the practical constraints on economic growth that inequality can impose. None of the 116 reviewed papers relates to inclusive development ${ }^{14}$. The strongest connection between ICTs and inclusion has been research on the digital divide. But, while the term did arise in the development informatics papers reviewed, the majority of occurrences were either historical quotes or within the reference lists.

Yet digital divides - note the plural - remain and develop: hundreds of millions have no mobile phone access; the Internet divide encompasses many more; the broadband divide is emergent; and the technology-access divide is far outstripped by the effective-informationuse divide (e.g. Ragnedda \& Muschert 2013). There are specific divides that impact particular groups - women (discussed below), youth, the disabled, ethnic minorities - for each of which there is a particular research agenda around the emerging nature of exclusion, and the framework for inclusive development (e.g. ITU 2013, Sinha \& Hyma 2013).

\footnotetext{
${ }^{13}$ Reflecting this - see Table C1 - 'money' and 'bank*' are barely under-represented in relative terms in DI research.

${ }^{14}$ One that notionally does so, in fact discusses open development, not inclusive development.
} 
But as with other topic areas, the challenge for development informatics research is to break out of the ICT4D bubble - in this case to do more than keep researching digital divides - and to engage with the breadth of inclusive development. For example, there are research agendas around related mechanisms - such as social protection - and around each fraction of inclusive development: inclusive growth, inclusive health, inclusive education, etc. One fraction of especial relevance to ICTs is "inclusive innovation" - the process and system by which new informatics-based goods and services are developed by and/or for excluded groups. For this, a set of future research priorities has already been laid out through a survey of ICT stakeholders: see Table 3 (Heeks et al 2013).

\begin{tabular}{|l|l|}
\hline Perspective & Research Priority \\
\hline STAKEHOLDER & - Policy for Inclusive Innovation \\
& - Grassroots Innovation \\
& - Inclusive Innovation Intermediaries \\
\hline SYSTEMIC & - Basics of Inclusive Innovation \\
& - New Models of Inclusive Innovation \\
& - Informatics and Inclusive Innovation \\
& - Benchmarks for Inclusive Innovation \\
\hline PROCESS & - Readiness for Inclusive Innovation \\
& - Inclusive Innovation Good Practice \\
& - Scaling Inclusive Innovations \\
& - Impact Evaluation of Inclusive Innovation \\
\hline
\end{tabular}

Table 3: Summary of Inclusive Innovation Research Priorities

Another relevant fraction will be "inclusive business models" given that ICTs are increasingly enabling those within base-of-the-pyramid communities to participate in business value chains. This may develop research on the use of ICTs to support inclusive value chains; for example, extending the work on "fair tracing" (Light 2010). Alternatively, it may research ICT-enabled business models such as "impact sourcing" - the outsourcing of ICT-related work to excluded and disadvantaged groups that creates new jobs, incomes and skills - for which a research agenda has already been identified (Heeks 2012).

7. Rights and Justice: none of the 116 reviewed papers specifically researches the issues of either rights or justice (though a couple dealing with capabilities, and with use of ICTs in reconciliation, do touch upon the issues). Yet, as seen above, these are emergent topics within the post-2015 agenda. They also have a clear relation to ICTs - for example in expression of rights online, in justice-based approaches to understanding ICT access, in debate over whether or not some component of ICT access represents a fundamental right, and in use of ICTs to support rights-based approaches to development (e.g. Rooksby \& Weckert 2007, Callanard 2013, EC 2013). 
8. Data Revolution: as noted in Section C2, data is - relative to some other informatics topics - under-researched vis-à-vis the post-2015 agenda. None of the reviewed papers focuses on any of the three data trends - open data, big data, and real-time data - and they are only mentioned a handful of times. Yet there is already growing interest in this area following the High-Level Panel Report (e.g. ODI 2013; see also identification of the "information revolution" in SDSN 2013), given the HLP (2013) explicitly called for a "data revolution" and suggested three data-related development targets:

"10b. Ensure people enjoy freedom of speech, association, peaceful protest and access to independent media and information ...

10d. Guarantee the public's right to information and access to government data ...

12f. Promote collaboration on and access to science, technology, innovation, and development data"

The most obvious evidence of a gap arises in relation to open data, with the analysis showing gaps around a data-oriented agenda that researches the role of ICTs in delivering improved transparency and accountability ${ }^{15}$. This (see the conceptualisation in Figure 16 of Heeks 2014) has most closely been associated with open government data (Davies et al 2013). However, open data initiatives and improvements in transparency and accountability can apply equally to private sector firms, markets, and NGOs (ibid.). Indeed, while there remains an important open government data research agenda, one could readily argue that the more neglected research area lies in connecting ICTs, openness and these latter development stakeholders.

There are three, related research agendas around big data: production, analysis, and use (Global Pulse 2013). The first two are somewhat generic and will have much in common with research on big data in the global North: researching mechanisms for capturing big data, for storing and distributing it, for ensuring data quality, techniques for analysing the data, and for visualising results. At present, though, the sense about big data and development is that it is a hammer looking for some nails: the key and specific research topic will be in understanding how development value can be extracted from big data through its effective use in development policy and practice decisions and actions.

In a similar way, the real-time data research agenda can be split into technical, sociotechnical and social components. The technical agenda will again relate to the data chain of capture, input, processing, storage and output. The socio-technical agenda follows on in understanding how best to analyse and present real-time data to users. But the most challenging and pertinent research will likely be that addressing the implications of real-time data for development systems that have evolved around assumptions of lagged data. In particular, the move to real-time data will allow a move to agile methods in development.

\footnotetext{
${ }^{15}$ There is a general research agenda on ICTs and open development which has been given major impetus by Canada's International Development Research Centre (Smith et al 2011). Elements of the broad scope of open development appear with just one or two mentions in the post-2015 documents - open innovation, open markets, open source. None of these topics was the specific focus for any of the reviewed research papers but their only-individual PTDA appearance, and the mid-table position for "open" in Table C1 provides only limited evidence to support the general open development agenda. However, one could argue there is more evidence if the close connection between openness and inclusion was acknowledged.
} 
There has been some initial work on agile as an ICT4D application development methodology (Dearden et al 2010, lacucci 2012, Haikin 2013) but this now needs expanding beyond the ICT4D bubble to research agile as an approach to development projects and processes generally; overlapping with the development management agenda discussed above.

Open, big and real-time data are three elements to the data revolution but there will be other elements to the research agenda that we can already pinpoint such as increases in geo-locatable data, mobile data, bottom-up data, and soft (qualitative e.g. emotionoriented) data. And there will also be emergent data trends that cannot yet be predicted.

9. Growth and Jobs: there is a general sense in which, relative to the forthcoming development agenda, current development informatics research is over-focused on social development and under-focused on economic development. That is not just a matter of the relative positions of 'economic' and 'social' in Table $\mathrm{C}^{16}$ but also reflected in the underrepresentation of 'income' and 'private' and 'business' in the table (see also Box 3); and in the under-representation of economics-based research within the papers reviewed.

Looking more specifically at growth and jobs, this can be something of an "everywhere but nowhere" research area because it can lie behind a lot of different issues while never quite being the main focus. None of the reviewed papers is explicitly focused on growth or jobs, but a number - such as the four related to enterprise and entrepreneurs - could be connected to this topic. So could the agenda above on agriculture, forming part of a more general inclusive growth focus, though in both cases there would be a particular direction in making the link to growth and jobs with specific questions about the link between ICTs and income growth, ICTs and productivity, and ICTs and job creation. As yet, these form only a small subset of work on ICTs and manufacturing/service/agricultural enterprise, and there are few if any studies on the role of ICTs specifically in high-growth micro/small enterprise.

Other fractions of a research agenda on ICTs and growth/jobs in development might lead to a reinvigoration of topics that were more to the fore in earlier waves of development informatics research (see Section $D$ below). These include macroeconomic investigations of the link between ICTs and GDP growth, studies of ICTs in medium and large enterprises, and research on the ICT sector itself which has been high growth and relatively labour-intensive. One aspect of the latter already noted can be work on inclusive ICT sector growth such as impact sourcing. Another would be tracking growth of digital enterprises, as "pure-play" digital business models become increasingly feasible within developing countries facilitated by incubator, hub, and similar support mechanisms.

\section{Box 3: Development Informatics Research and the Private Sector}

This paper discusses the relation of development informatics research to the development agenda as promoted by the "development community" of multilateral and bilateral international organisations, governments, NGOs, etc. It assumes

\footnotetext{
${ }^{16}$ Part of the latter relates to discussion of social media and social networks in the DI research, but that would not account for all over-representation, let alone the relative difference between 'economic' and 'social'.
} 
funding will come from within this community. But what of the private sector, which may also be a DI research funder, and which will have its own business-anddevelopment agenda? In some ways that agenda will overlap with the issues outlined in the main body of the paper:

- The big issues of sustainability, resilience, climate change and environment will increasingly force their way onto corporate agendas if they are not there already. - Lean and agile methods are an important trend within business.

- Many businesses are involved in the food and agriculture sectors.

- Financial issues are central to all businesses, from sourcing capital to paying tax. - Inclusive innovation and inclusive business models are, centrally, about the private sector.

- The data revolution is sweeping business as much as other sectors.

- Issues of international trade and movement of capital are foundational to globalised businesses.

As noted in the main text, all of these have ICT-related elements that can form part of a development informatics research agenda. But in all cases, the particular direction of any private sector-oriented and/or -funded research agenda will be business-specific and perhaps a little different to that outlined above. For example, private sector interest in resilience is driven by concerns to maintain supply chains and profits in the face of shocks (Rosic et al 2009); inclusivity is often framed in terms of base-of-the-pyramid models (London 2007); and any interest in governance might well be shaped by worries about regulatory burden (Kirkpatrick et al 2006). Taking the second topic as an example, private sector-oriented DI research might look at how to use ICTs to help business better design for, market to, and supply low-income consumers with new goods and services.

Beyond those issues mentioned, almost all of the growth and jobs agenda above related to enterprise and business. In particular, DI research for business would need to cover all aspects of e-business in developing countries, all aspects of the ICT sector in developing countries, and all aspects of their intersection - new digital enterprises.

The relationship of business to development has always seen a tension between corporate social responsibility and profit (Karnani 2010), so DI research is likely to cover both components. But that tension - also reflected in the terminology of "developing countries" vs. "emerging economies" - leads into the debate about where such activity is located. Is this part of ICT4D or of some broader church, such as "ICTs in developing countries" or "ICTs in emerging economies"?

10. Security and Violence: although insecurity overall was shown as declining somewhat within the post-2015 agenda, this was not true of security and violence specifically, and the overall topic has been continuously under-represented within development informatics. Past work (e.g. Hattotuwa 2004, Heeks \& Konkel 2009) and particularly that from Georgia Tech (e.g. Best et al 2010, Best 2013) points to a broad range of issues for future research: across the cycle from insecurity through conflict to post-conflict reconstruction, 
reconciliation and peacebuilding; from the micro of violence within households to the macro of regional warfare; and bringing in issues from application design and implementation to strategic and policy matters. There will also be a growing need for work looking specifically at cyber-security in developing countries.

11. Gender/Women: the third wave of development informatics research (see below) was marked by a significant upswing in activity on this topic; particularly looking at the gender divide in access, use and benefits of ICTs, and in the ICT sector (e.g. Huyer \& Sikoska 2003, $\mathrm{Ng} \&$ Mitter 2005). There continues to be a strong vein of work - stronger in looking at women and ICTs than at exploring gender norms/relations and ICTs - and there is some reflection of this in the reviewed papers: five of the 116 are specifically on this topic area and a number of others have some gender disaggregation in presenting their results, or include issues with an explicit gender dimension such as child development and particular fractions of healthcare. However, the upgrowth in presence of women's development and of gender in the post-2015 agenda suggests a potential need for a further expansion of work within development informatics. The research agenda here is very broad, potentially touching all aspects of ICTs' relation to economic, social, political and environmental development.

12. Cross-Border Flows: globalisation - partly facilitated by ICTs - has meant increasing global connections and increasing global flows of labour, of capital, and of goods and services. As the post-2015 agenda recognises, this is only going to accelerate in future. Yet, and despite the integral and growing role of ICTs in most cross-border flows, this is not an issue that has figured very much within development informatics research. There is a thread of work - reflected in the papers reviewed - looking at ways in which ICTs support families in which members have migrated overseas, as well as work studying the migration of ICT-skilled workers. In relative terms (see Table C1), then, migration has been better covered - at least within the development informatics research community - than issues around ICTs and global trade and ICTs and global investment. The former may be implicitly covered in discussions about commerce - as in e-commerce - but neither that nor trade were the explicit focus for any of the reviewed papers. As with some other topics reviewed here, this was part of the earlier agenda within development informatics (e.g. Mansaray 1992) that will now need to be revived. The latter - investment - was also discussed under Topic 5.

13. Resilience: resilience - the capacity "to withstand and recover from short-terms shocks, and to adapt to long-term trends" (Heeks \& Ospina 2013) - is very much associated with the environment and sustainability agenda. However, it has outgrown its environmental (climate change/disasters) roots to be seen as a cross-cutting property that all systems from individuals and households through communities and organisations and value chains to cities, regions and nations - require. And it has outgrown its sustainability roots to be seen as a property to help systems not only sustain but also transform. It has thus developed sufficient momentum - with a number of major resilience initiatives already underway in development - to justify a specific presence in this discussion.

Resilience has risen so recently and so sharply up the development agenda that it is no surprise that development informatics research has been left trailing. It is barely mentioned 
in the papers reviewed and is far off forming a section of interest within a paper, let alone the focus for a paper. As such, the initial research agenda will be quite foundational: understanding conceptualisations of resilience of particular relevance to ICTs (e.g. models of 'e-resilience': Ospina \& Heeks 2010); developing tools and metrics; understanding how ICTs impact resilience (e.g. Heeks \& Ospina 2013); and understanding how resilience applies to ICTs e.g. in seeking to make ICT-based systems more resilient to external threats (Müller et al 2013).

Although encompassed by the overall interest in resilience, there may also be specific work to be undertaken in researching its antithetical components that appear in the top half of Table C1, such as: the relation of ICTs to fragility and vulnerabilities (something potentially covered by the sustainable livelihoods framework); to volatility; and to risks, shocks and crises.

In toto, while there is a significant connection in all this to sustainability informatics, the specific issue of resilience informatics and its mirror image will need to form their own particular sub-domain of research activity.

14. Governance: 'government', 'governance', 'institutions', 'civil society' and 'state(s)' all appear as relatively under-represented terms in Table C1. None of them expands greatly within the post-2015 agenda compared to the MDGs but overall they retain a sizeable presence within that agenda. Even more so if we include the 'policies' and 'laws' that are typically enacted by elements of the state. There has been a sizeable tradition of work within development informatics on e-government (e.g. Ndou 2004), e-governance more broadly (e.g. Madon 2009), and using institutional perspectives (e.g. Avgerou 2002). Institutional work is moderately represented in the reviewed DI papers compared to other topics - three of the 116 are specifically about institutions, and very many more discuss institutional issues. The slight surprise is that only one paper is explicitly about egovernment/e-governance research (though very many more - e.g. most of the e-health papers - are about use of ICTs in the public sector). At least on the basis of the basket of terms used in relation to the papers reviewed here, more should be done to deepen our understanding of the role of ICTs in all processes of governance.

15. Urban Development: this topic did not show a particularly dramatic rise in the post2015 agenda and its overall presence is relatively low compared to other development issues. There is some relative under-representation in the current DI research which was reviewed, even though three of the papers explicitly look at issues in urban areas. So, the data is not as strong as for other topics in suggesting the need for an expansion in urban informatics research in future years ${ }^{17}$. Inclusion comes partly because this issue is explicitly flagged in post-2015 documents (e.g. HLP 2013, SDSN 2013). And partly from the demographic certainty that urban populations are rising: the global tipping point of greater urban than rural population was reached in 2008; that point will be reached for developing countries by 2030; and poverty and many other development challenges are necessarily

\footnotetext{
${ }^{17}$ One might try to make a stronger case for a broader agenda item - on places or geography of development - which would include the under-represented terms 'small island' and 'landlocked'. But that would be a diverse and uneven topic area, and 'geograph*' itself plus other place-based concepts - 'rural', 'local' - were not under-represented.
} 
rising faster in urban than rural areas (Beall et al 2010). The volume of research on urban informatics and development will need to rise concurrently.

\section{C4. Transformative Development and Development 2.0}

In putting together the priorities listed above, I have thought about the implications of all terms that were less than or equal to -0.5 , or more than or equal to +0.5 in Table $\mathrm{C}^{18}$. But now one term remains to discuss - 'transform*' - a term which appears roughly four times more often in the post-2015 literature than it does in the sample of development informatics research.

As noted in Heeks (2014), there is a leitmotif of transformation within the post-2015 agenda to date; a belief that the incremental developmental changes achieved to date will no longer be sufficient in the remainder of the $21^{\text {st }}$ century; and an aspiration for a step-change in approach. The initial foundation for the post-2015 agenda (UN 2012:i) states "Business as usual thus cannot be an option and transformative change is needed", and its successor (UN 2013:1) speaks of the need to facilitate "transformational change". Going further, the HighLevel Panel report (HLP 2013) puts a central emphasis on five "transformative shifts" that need to drive the post-2015 agenda:

"1. Leave no one behind. ...

2. Put sustainable development at the core. ...

3. Transform economies for jobs and inclusive growth. ...

4. Build peace and effective, open and accountable institutions for all. ...

5. Forge a new global partnership."

What this notion of transformation means in practice is rather fuzzy. Sometimes it seems to mean just more of what is already being done - pushing on with the MDG agenda, with openness and accountability, with multi-stakeholder partnerships. Sometimes it means not just doing more but doing it somewhat differently e.g. to include those who have hitherto been excluded. And at other times there is more a sense of step change e.g. in seeking to make development sustainable for the future or, very occasionally, in challenging the current structures of international development (though with no detail on what such a structural transformation might entail).

What does all this mean for development informatics research?

Given the under-representation shown in Table C1, it suggests we need to be doing more research on the relation between ICTs and the transformation of development. There is already a general orientation for such research - development 2.0 - defined as "new ICTenabled models that can transform the processes and structures of development" (Heeks $2010 \mathrm{~d}: 1)^{19}$. But defining the content of a development 2.0 research agenda more precisely has been difficult owing to the fuzziness of the underlying concept of developmental transformation.

\footnotetext{
${ }^{18}$ The only two terms which, as a result, did not find a clear connection with the discussion above were 'resource' and 'services'; seen as too generic.

19 '2.0' itself appears nowhere in the PTDA, and just over 100 times in the DI research papers; mostly relating to either the Heeks or Thompson papers cited here, or to Heeks' (2008) analysis of 'ICT4D 2.0'.
} 
First, there is the threshold problem - when is a change sufficiently large to be classified as 'transformative' as opposed to just 'incremental'? Second, there is the direction problem transformation of what? Of context (e.g. structures)? Of inputs (e.g. goals, visions, aspirations)? Of processes (e.g. business models, partnerships)? Of outputs (e.g. inclusion, sustainability)?

So we have problems defining transformation in terms of both extent and content. Heeks' Development 2.0 definition above was a mix of process and structure; identifying three "potentially-transformative" ICT-enabled models - direct development, networked development, grassroots development. So it misses some possible aspects of content, it has no clear answer to the threshold problem, and it lacks a strong conceptual foundation (though might seek the latter either in the ideas of complex adaptive systems or in the ideas of sustainability). But both Heeks (ibid.) and Thompson (2008) identify ICTs as the mechanism that will enable - and might even drive - some transformation of development.

Thus, Development 2.0 should clearly be part of the future development informatics agenda, and should be a priority. Hence, its inclusion in Table 2. But foundational work is needed to conceptualise the meaning of both developmental transformation and Development 2.0 before a clear research agenda can emerge. Hence, as yet, its only-partial inclusion in Table 2.

The best we have at present would be a modification of Mark Thompson's (2008:832) formulation: "a strand of research that seeks a conscious and sustained dialogue between [ICT-enabled] models and ways of thinking, and the broader debates and structural concerns [around transformation] within development studies". This is still very general, and explains the contingent inclusion of Development 2.0 as a future DI research priority: subject to an understanding that basic groundwork will be the first activity needed.

\section{C5. Undertaking Future Development Informatics Research}

The focus above and in the summary that follows is on research content: what topics to research. But we should also give some thought to research process: how to research development informatics.

I have already written on this to some extent, particularly in relation to the process of research publication:

- Overviewing general quality and impact of development informatics research (Heeks 2010a).

- Identifying the best form of publication - book, book chapter, journal article, conference paper - for maximum impact (Heeks 2010b).

- Selecting which ICT4D journal to publish in (Heeks 2010c) or which development studies journal to publish in (Heeks 2010f).

Here, I will just repeat a brief section from an earlier publication (Heeks 2009), which draws out three good practices in development informatics research that are seen to be epitomised by Rob Jensen's paper on mobile phone use by Keralan fishermen (Jensen 2007): 
a) "Audience Focus and Dissemination: good ICT4D research identifies, focuses on and targets its particular audience. Jensen is an academic economist. He did this research and he wrote up this research for other academic economists. He chose an appropriate channel - a leading economics journal - to reach that audience. (And then reached much further through having the work summarised in The Economist.)

b) Conceptual Foundation: good ICT4D research is founded on and structured around some conceptual framework or model. Without that, research struggles for coherence and consistency. With that, it is more likely to make a longer-term contribution. Jensen's work is rooted in welfare economics theory, to which it also makes a contribution.

c) Rigorous Methods: good ICT4D research has a methodology, and rigorously applies appropriate research methods. It also explains the methodology, methods and their application to its readers. Good narratives about ICT4D win hearts. Good quantitative statistics win minds. But too much ICT4D "research" falls down in between:

methodology-less, wishy-washy qualitative data that wins nothing. Jensen's research avoids this: it has a rigorous quantitative foundation built on shed-loads of longitudinal field data."

Introducing rigour into one's DI research is a relatively straightforward process given the plethora of guides on research methods including some which are specific to the field (e.g. Chib \& Harris 2012). More difficult will be determining one's audience. Figure 1 presents the main choices - the cognate fields of either development studies or some fraction of informatics studies, or the specific audience of development informatics - but there are many other cognate fields (see Heeks 2010e for an overview). Most difficult is probably identifying an appropriate conceptual foundation. There is some review of possibilities in Heeks \& Molla (2009) but this is not comprehensive, nor does it reflect the issues of audience and "fast currents" which shape theory choice. 


\section{The Past and Future of Development Informatics Research}

One can distinguish four waves of development informatics research to date:

- Wave One (1960s to mid-1980s): work here made the first links between ICTs and development; there were strong connections to the technology transfer agenda, and to modernisation and then structuralist notions of development; there were few connections to the information systems discipline; and there was a good mix of academic and policy/development organisation involvement.

- Wave Two (mid-1980s to mid-1990s): the area was given significant academic impetus with the formation of Information Technology for Development journal ${ }^{20}$ and the IFIP WG9.4 academic group on "Social Implications of Computers in Developing Countries". The space was particularly populated by information systems academics who brought in a research agenda with interests in socio-technical systems analysis and design, and cultural and other contextual issues. But the space itself was small: at most a few dozen academics appeared active globally.

- Wave Three (mid-1990s to mid-2000s): there was a massive expansion of research during this period due to the arrival of the Internet into mainstream activities in the global North, and the associated growth of debate and funding about ICTs and development. The two other core development informatics journals - the Electronic Journal of Information Systems in Developing Countries and Information Technologies and International Development - were founded during this period. Despite the work undertaken during the first two waves, there was a 'year zero' feel to much of the research, given it was undertaken by newcomers to the field. As per Figures 4 and 5 (adapted from Heeks 2010e), the focus was on the initial parts of the ICT4D value chain around readiness and availability issues - access, the digital divide - and any uptake/impact evidence was often based just on pilots and prototypes.

- Wave Four (mid-2000s to mid-2010s): there have been a number of concurrent trends alongside the initial slide of ICTs from the development agenda during this period followed by its less-than-full recovery as mobiles diffused. Following Figures 4 and 5, there has been a shift of attention to later parts of the ICT4D value chain with more robust evidence about the impact of ICTs in development. There has been some intellectual consolidation: for example building some corpus of work around particular conceptualisations such as Sen's capability approach, actor-network theory, or the technology acceptance model (Andersson \& Hatakka 2013). There have also been two expansions. First a geographic one as greater research capacity has been built in developing countries both as a natural consequence of growth in higher education, and through more directed initiatives such as the IDRC-funded SIRCA programmes (see http://www.sirca.org.sg/). Second a disciplinary one with the harder informatics disciplines - computer science, human-computer interaction - engaging for the first time; facilitated most especially by the advent of the ICTD series of conferences in 2006.

\footnotetext{
${ }^{20}$ See Appendix D on development informatics journal start dates.
} 
Enablers

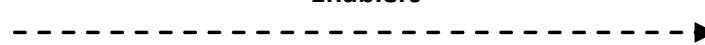

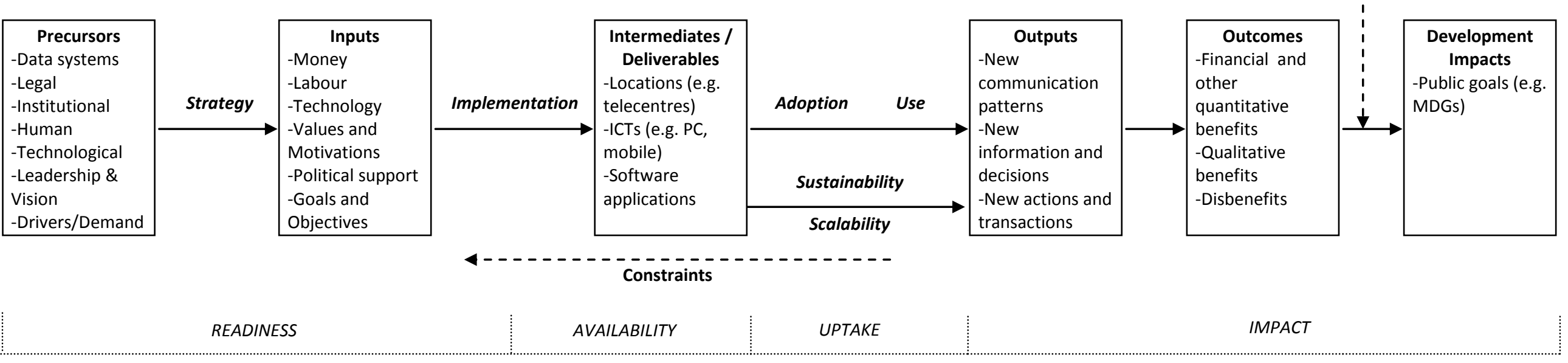

Figure 4: The ICT4D Value Chain 


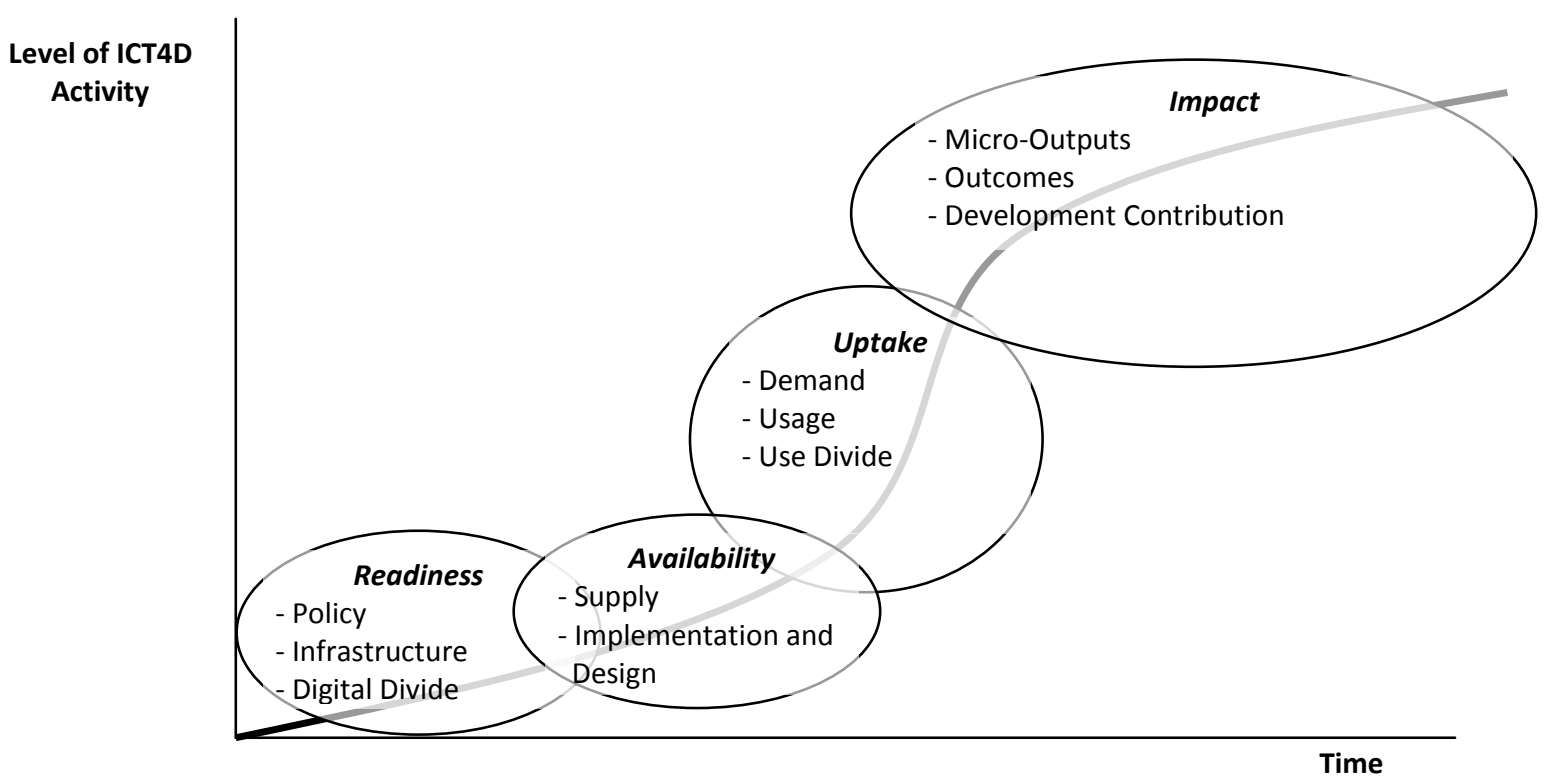

Figure 5: Changing Focus of Development Informatics Research Priorities Over Time

What then for the fifth wave of development informatics research; from the mid-2010s onwards? Table 2 sets out the current best analysis for key research gaps that need to be filled during the fifth wave. These do not represent the totality of DI research priorities; they represent those post-2015 topics which have been most under-represented. Thus work on, for example, ICTs and health, ICTs and education/learning, ICTs and enterprise, will need to continue during this period. And there will need to be new work on emerging ICT topics.

Figure 6 attempts to put all this together as a DI research priority map. Vertically, it sorts research issues in terms of gap and, hence, priority for additional attention: the higher up the diagram, the higher the priority. Laterally, it sorts research issues in terms of their relation to development (mainly types of goal, including cross-cutting, but also including development mechanisms). 

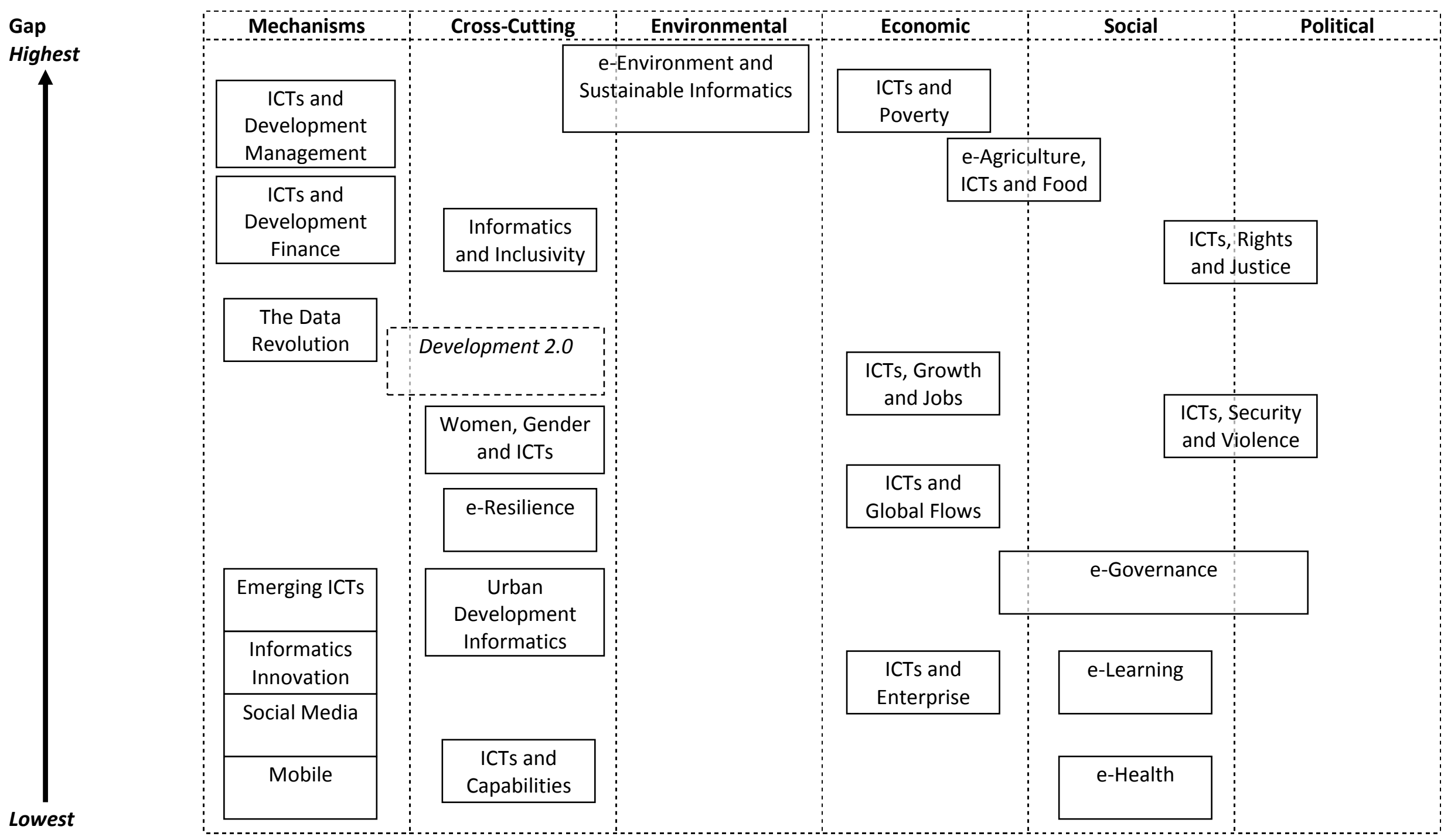

Figure 6: Map of Post-2015 Development Informatics Research Priorities 
But, if these new, additional priorities are picked up, is there some greater coherence that could be created from the topics? There was a recurrent theme encouraging development informatics research to break out of the ICT4D bubble and investigate the role of informatics in the development mainstream. But is there some narrative that cuts across the various topics outlined? Of course there are overlaps - openness allows inclusion of previously excluded groups; greater equality for women draws on both inclusive and rights-based development notions; poverty relates to many of the other topics. But the only candidates for dominance are sustainable development and, possibly, inclusive development.

For the earlier waves (see Figure 7), we can summarise key focal areas for DI research:

- First wave: modernisation and transfer

- Second wave: systems and context

- Third wave: access and potential

- Fourth wave: design and impact

There have been attempts at creating a single, if not narrative than at least terminology, for future research such as "ICT4D 2.0" (Heeks 2009) or "Development 2.0" (Thompson 2008, Heeks 2010d). As discussed above, "Development 2.0" will be part of the fifth wave and is the means by which we research the connection between ICTs and the key post-2015 aspiration for development to be more transformational. This could gather momentum and become the nucleus for post-2015 thinking on development and, hence, become an overarching idea within development informatics. Or it might just form one fragment among many parts of the development informatics domain.

It therefore remains to be seen whether Development 2.0 - or something else such as "sustainable informatics" or "inclusive informatics" - can create enough coherence and acceptance to become a dominant narrative for post-2015 development informatics research.

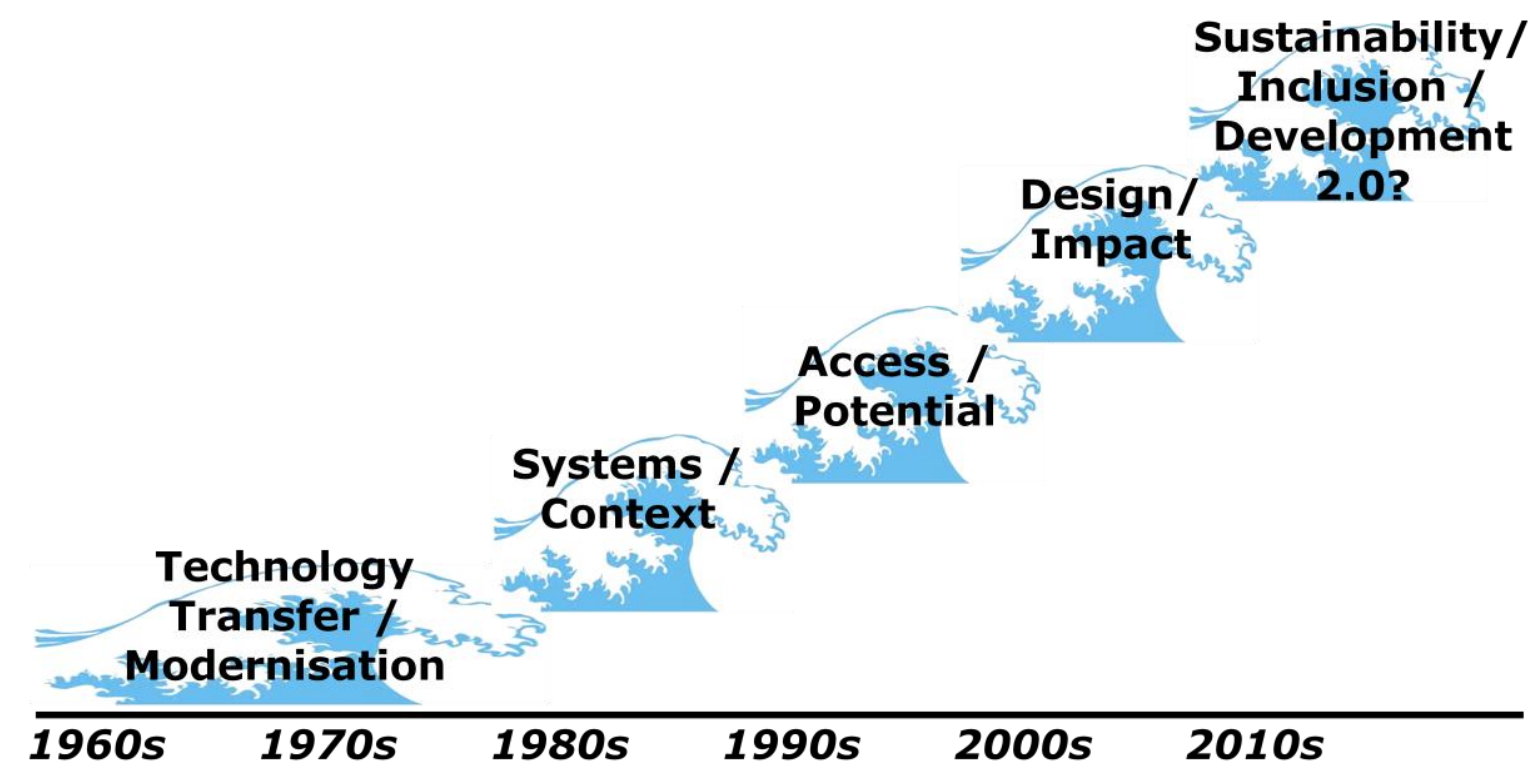

Figure 7: The Five Waves of Development Informatics Research 


\section{References}

Andersson, A., Gronlund, A. \& Wicander, G. (2012) Development as freedom: how the capability approach can be used in ICT4D research and practice (editorial), Information Technology for Development, 18(1), 1-4

Andersson, A. \& Hatakka, M. (2013) What are we doing? Theories used in ICT4D research, paper presented at IFIP WG9.4 $12^{\text {th }}$ International Conference on Social Implications of Computers in Developing Countries, Ocho Rios, Jamaica, 19-22 May

Avgerou, C. (2002) Information Systems and Global Diversity, Oxford University Press, Oxford, UK

Beall, J., Guha- Khasnobis, B. \& Kanbur, R. (eds) (2010) Urbanisation and Development, Oxford University Press, Oxford, UK

Best, M.L. (2013) Peacebuilding in a networked world, Communications of the ACM, 56(4), 30-32

Best, M.L., Smyth, T.N., Etherton, J. \& Wornyo, E. (2010) Uses of mobile phones in postconflict Liberia, Information Technologies and International Development, 6(2), 91-108

Callanard, A. (2013) Human rights and information and communication technology, paper presented at ASEM Seminar on Human Rights, Seoul, 27-29 Jun http://www.article19.org/resources.php/resource/37128/en/human-rights-andinformation-and-communication-technology

Chib, A. \& Harris, R. (eds) (2012) Linking Research to Practice: Strengthening ICT for Development Research Capacity in Asia, ISEAS Publishing, Singapore

Davies, T., Perini, F. \& Alonso, J.M. (2013) Researching the Emerging Impact of Open Data, ODDC Working Paper 1, Open Data Research Network http://www.opendataresearch.org/sites/default/files/posts/Researching\%20the\%20emergi ng\%20impacts\%20of\%20open\%20data.pdf

Dearden, A., Rizvi, H. \& Gupta, S. (2010) Roles and responsibilities in agile ICT for development, Electronic Workshops in Computing, 1-12

Denizer, C., Kaufmann, D. \& Kraay, A. (2011) Good Countries or Good Projects?, Policy Research Working Paper 5646, World Bank, Washington, DC

Duncombe, R. \& Boateng, R. (2009) Mobile phones and financial services in developing countries: a review of concepts, methods, issues, evidence and future research directions, Third World Quarterly, 30(7), 1237-1258 
EC (2013) ICT Sector Guide on Implementing the UN Guiding Principles on Business and Human Rights, European Commission, Brussels

http://ec.europa.eu/enterprise/policies/sustainable-business/files/csr-sme/csr-ict-hrbusiness en.pdf

Gill, K., Warner, A., Weiss, E. \& Gupta, G.R. (2009) From beneficiaries to change agents: the rise of women's leadership in international development, SAIS Review, 29(2), 23-38

Global Pulse (2013) United Nations Global Pulse, United Nations, New York, NY http://www.un.org/millenniumgoals/pdf/GP\%20Backgrounder-General2013 Sept2013.pdf

Haikin, M. (2013) Reflections on Applying Iterative and Incremental Software Development Methodologies (Agile, RAD etc) to Aid and Development Work in Developing Countries http://matthaikin.files.wordpress.com/2013/03/agile-blarticle-part-11.pdf

Hattotuwa, S. (2004) Untying the Gordian knot: ICT for conflict transformation and peacebuilding, Dialogue, 2(2), 39-58

Heeks, R.B. (2008) ICT4D2.0: the next phase of applying ICT for international development, IEEE Computer, 41(6), 26-33

Heeks, R.B. (2009) The ICT4D 2.0 Manifesto: Where Next for ICTs and International Development, Development Informatics Working Paper 42, Centre for Development Informatics, University of Manchester, UK http://www.seed.manchester.ac.uk/subjects/idpm/research/publications/wp/di/

Heeks, R. (2010a) ICT4D research: quality and impact, ICT4DBlog, 23 Feb http://ict4dblog.wordpress.com/2010/02/23/ict4d-research-quality-and-impact/

Heeks, R.B. (2010b) ICT4D research: how should I publish?, ICT4DBlog, 31 Mar http://ict4dblog.wordpress.com/2010/03/31/ict4d-research-how-should-i-publish/

Heeks, R.B. (2010c) ICT4D journal ranking table, ICT4DBlog, $14 \mathrm{Apr}$ http://ict4dblog.wordpress.com/2010/04/14/ict4d-journal-ranking-table/

Heeks, R.B. (2010d) Development 2.0: the IT-enabled transformation of international development, Communications of the ACM, 53(4), 22-24

Heeks, R.B. (2010e) Do information and communication technologies (ICTs) contribute to development?, Journal of International Development, 22(5), 625-640

Heeks, R. (2010f) Development studies journal ranking table, ICT4DBlog, 17 Jun http://ict4dblog.wordpress.com/2010/06/17/development-studies-journal-ranking-table/

Heeks, R.B. (2012) The research agenda for IT impact sourcing, ICT4DBlog, 6 May http://ict4dblog.wordpress.com/2012/05/06/the-research-agenda-for-it-impact-sourcing/ 
Heeks, R.B. (2014) From the MDGs to the Post-2015 Agenda: Analysing Changing Development Priorities, Development Informatics Working Paper 56, Centre for Development Informatics, University of Manchester, UK http://www.seed.manchester.ac.uk/subjects/idpm/research/publications/wp/di/

Heeks, R.B. \& Molla, A. (2009) Impact Assessment of ICT-for-Development Projects: A Compendium of Approaches, Development Informatics Working Paper 36, Centre for Development Informatics, University of Manchester, UK http://www.seed.manchester.ac.uk/subjects/idpm/research/publications/wp/di/

Heeks, R.B. \& Konkel, A. (2009) Challenging conventional views on mobile telecommunications investment: evidence from conflict zones, Development in Practice, $19(3), 414-420$

Heeks, R.B. \& Ospina, A.V. (2013) Understanding Urban Climate Change and Digital Infrastructure Interventions from a Resilience Perspective, Development Informatics Working Paper 54, Centre for Development Informatics, University of Manchester, UK http://www.seed.manchester.ac.uk/subjects/idpm/research/publications/wp/di/

Heeks, R.B., Amalia, M., Kintu, R. \& Shah, S. (2013) Inclusive Innovation: Definition, Conceptualisation and Future Research Priorities, Development Informatics Working Paper 53, Centre for Development Informatics, University of Manchester, UK http://www.seed.manchester.ac.uk/subjects/idpm/research/publications/wp/di/

Hill, J. (2013) Lean innovation in international development, Polymath, 21 Aug http://www.polymathv.com/lean-innovation-in-international-development-2/

HLP (2013) A New Global Partnership: Eradicate Poverty And Transform Economies Through Sustainable Development, High-Level Panel of Eminent Persons, United Nations, New York http://www.post2015hlp.org/wp-content/uploads/2013/05/UN-Report.pdf

Huyer, S. \& Sikoska, T. (2003) Overcoming the Gender Digital Divide: Understanding ICTs and their Potential for the Empowerment of Women, UN-INSTRAW, Santo Domingo, Dominican Republic

lacucci, A.A. (2012) An agile development manifesto for ICT4D projects, CrisisMapper blog, 20 August http://crisismapper.wordpress.com/2012/08/20/agile-development-manifestofor-ict4d-projects/

ITU (2013) The ICT Opportunity for a Disability-Inclusive Development Framework, International Telecommunication Union, Geneva http://www.itu.int/en/action/accessibility/Documents/The\%20ICT\%200pportunity\%20for\% 20a\%20Disability Inclusive\%20Development\%20Framework.pdf

Jensen, M. (2007) The digital provide: information (technology), market performance, and welfare in the South Indian fisheries sector, The Quarterly Journal of Economics, 122(3), 879924 
Karnani, A. (2010) The case against corporate social responsibility, Wall Street Journal, 23, 15

Kirkpatrick, C., Parker, D., \& Zhang, Y. F. (2006) Foreign direct investment in infrastructure in developing countries: does regulation make a difference?, Transnational Corporations, 15(1), 143-171

Kleine, D. (2013) Technologies of Choice?: ICTs, Development, and the Capabilities Approach, MIT Press, Cambridge, MA

Light, A. (2010) Bridging global divides with tracking and tracing technology, Pervasive Computing, 9(2), 28-36

London, T. (2007) A Base-of-the-Pyramid Perspective on Poverty Alleviation, William Davidson Institute, University of Michigan, Ann Arbor, MI

Madon, S. (2009) e-Governance for Development: A Focus on Rural India, Palgrave Macmillan, London

Mansaray, M. L. (1992) ASYCUDA: a framework for an integrated socio-economic development of ECOWAS countries, in: Social Implications of Computers in Developing Countries, S.C. Bhatnagar \& M. Odedra (eds), Tata McGraw-Hill, New Delhi, 244-260

Müller, G., Koslowski, T. G. \& Accorsi, R. (2013) Resilience - a new research field in business information systems?, in: Business Information Systems Workshops, Springer, Berlin, 3-14

Ndou, V. (2004) E-government for developing countries: opportunities and challenges, Electronic Journal of Information Systems in Developing Countries, 18(1), 1-24

Ng, C. \& Mitter, S. (2005) Gender and the Digital Economy, Sage Publications, New Delhi

ODI (2013) What kind of data revolution do we need for post-2015?, Post2015.org, 5 Nov http://post2015.org/2013/11/05/launch-of-a-new-blog-series-what-kind-of-datarevolution-do-we-need-for-post-2015/

Ospina, A.V. \& Heeks, R. (2010) Linking ICTs and Climate Change Adaptation: A Conceptual Framework for e-Resilience and e-Adaptation, Centre for Development Informatics, University of Manchester, UK http://www.niccd.org/sites/default/files/ConceptualPaper.pdf

Ospina, A.V. \& Heeks, R.B. (2012) The Future Research Agenda for ICTs, Climate Change and Development, Centre for Development Informatics, University of Manchester, UK http://www.niccd.org/sites/default/files/ICCD Future Research Agenda Strategy Brief.pd $\underline{f}$

Ragnedda, M. \& Muschert, G.W. (eds) (2013) The Digital Divide: The Internet and Social Inequality in International Perspective, Routledge, London 
Renken, J. \& Heeks, R. (2013) Conceptualising ICT4D project champions, in: Proceedings of the $6^{\text {th }}$ International Conference on Information and Communication Technologies and Development, Vol. 2, 128-131

Rooksby, E. \& Weckert, J. (eds) (2007) Information Technology and Social Justice, IGI Global, Hershey, PA

Rosic, H., Bauer, G. \& Jammernegg, W. (2009) A framework for economic and environmental sustainability and resilience of supply chains, in: Rapid Modelling for Increasing Competitiveness, G. Reiner (ed), Springer, London: 91-104

Schiffer, E. (2011) Agile international development?, Net-Map, 29 Sept http://netmap.wordpress.com/2011/09/29/agile-international-development/

SDSN (2013) An Action Agenda for Sustainable Development, Sustainable Development Solutions Networks, Paris http://unsdsn.org/files/2013/11/An-Action-Agenda-forSustainable-Development.pdf

Sinha, C. \& Hyma, R. (2013) ICTs and social inclusion, in: Connecting ICTs to Development, L. Elder, H. Emdon, R. Fuchs \& B. Petrazinni (eds), Anthem Press, London, 91-116

Smith, M.L., Elder, L. \& Emdon, H. (2011) Open development: a new theory for ICT4D, Information Technologies and International Development, 7(1), iii-ix

Thompson, M. (2008) ICT and development studies: towards development 2.0, Journal of International Development, 20(6), 821-835

UN (2012) Realizing the Future We Want for All, United Nations, New York, NY http://www.un.org/en/development/desa/policy/untaskteam undf/untt report.pdf

UN (2013) A Renewed Global Partnership for Development, United Nations, New York, NY http://www.un.org/en/development/desa/policy/untaskteam undf/glob dev rep 2013.pd $\underline{f}$

UNGA (2012) The Future We Want, A/RES/66/288, United Nations General Assembly, New York, NY http://www.un.org/ga/search/view doc.asp?symbol=A/RES/66/288\&Lang=E 


\section{Appendix A: Most Frequently-Appearing Terms in Current Development Informatics Research}

The table lists the twenty most frequently-appearing terms within the development informatics research documentation, from among those terms used within the current analysis, selected on the basis of their frequency per 10,000 words of text.

\begin{tabular}{|r|l|c|}
\hline Position & Term & $\begin{array}{c}\text { Freq. } \text { per } \\
\mathbf{1 0 , 0 0 0} \text { Words }\end{array}$ \\
\hline 1 & ICT & 48.8 \\
\hline 2 & Information & 44.0 \\
\hline 3 & Technol* & 42.0 \\
\hline 4 & Social & 39.4 \\
\hline 5 & System* & 34.1 \\
\hline 6 & Health & 31.8 \\
\hline 7 & Comput* & 27.1 \\
\hline 8 & Mobile & 24.8 \\
\hline 9 & Data & 21.6 \\
\hline 10 & Phone & 19.2 \\
\hline 11 & Communit* & 18.6 \\
\hline 12 & Particip* & 17.1 \\
\hline 13 & Network & 15.3 \\
\hline 14 & Process* & 15.1 \\
\hline 15 & Public & 14.0 \\
\hline 16 & Local & 12.2 \\
\hline 17 & Government & 12.0 \\
\hline 18 & Universit* & 10.9 \\
\hline 19 & Education & 10.9 \\
\hline 20 & Economic & 10.5 \\
\hline & & \\
\hline
\end{tabular}




\section{Appendix B: Composition of Key Development Issues}

The table shows the component words/terms that were aggregated to form the 25 key development issues reported in the main text. Coverage is not comprehensive of every possible term and issue but as noted in the main text, these were developed on the basis of both word counts and broader literature review.

\begin{tabular}{|c|c|}
\hline \multicolumn{2}{|l|}{ DEVELOPMENT GOALS } \\
\hline \multirow[t]{12}{*}{ MDGs 1-6 } & Poverty \\
\hline & Hunger \\
\hline & Education \\
\hline & Child \\
\hline & Women \\
\hline & Gender \\
\hline & Girl \\
\hline & Maternal \\
\hline & Health \\
\hline & Mortality \\
\hline & HIV/AIDS \\
\hline & Malaria \\
\hline \multirow[t]{5}{*}{ Growth and Enterprise } & Growth \\
\hline & Enterprise \\
\hline & Entrepreneur \\
\hline & Employ* \\
\hline & Job \\
\hline \multirow[t]{2}{*}{ Rural/Agricultural Development } & Agric* \\
\hline & Rural \\
\hline \multirow[t]{2}{*}{ Urban Development } & Urban \\
\hline & City/Cities [whole words] \\
\hline \multirow[t]{3}{*}{ Institutional Development } & Governance \\
\hline & Institution \\
\hline & Politic* \\
\hline \multirow[t]{3}{*}{ Rights and Justice } & Justice \\
\hline & Rights \\
\hline & Social Justice \\
\hline \multirow[t]{3}{*}{ Livelihoods } & Livelihood \\
\hline & Capabilit* \\
\hline & Vulnerab* \\
\hline Migration & Migra* \\
\hline Manufacturing & Manufacturing \\
\hline Services & Services \\
\hline Infrastructure & Infrastructur* \\
\hline \multirow[t]{4}{*}{ Insecurity } & Conflict \\
\hline & Humanitarian \\
\hline & Violen* \\
\hline & War(s) [whole words] \\
\hline
\end{tabular}




\begin{tabular}{|c|c|}
\hline & Peace \\
\hline & Security \\
\hline \multirow[t]{6}{*}{ MDG 8} & Trade \\
\hline & Least developed \\
\hline & Landlocked \\
\hline & Small island \\
\hline & Debt \\
\hline & Drug \\
\hline \multirow[t]{3}{*}{ Wellbeing } & Psychol* \\
\hline & Happy/Happiness \\
\hline & Well-being/Wellbeing \\
\hline \multirow[t]{6}{*}{ Environment and Sustainability } & Environment* \\
\hline & Sustainab* \\
\hline & Climate Change \\
\hline & Energy \\
\hline & Disaster \\
\hline & Waste \\
\hline \multirow[t]{4}{*}{ Open Development } & Open [not Copenhagen] \\
\hline & Transparen* \\
\hline & Accountab* \\
\hline & Corrup* \\
\hline \multirow[t]{6}{*}{ Inclusive Development } & Inclusi* \\
\hline & (In)equalit* \\
\hline & Exclusion/Excluded \\
\hline & Diversity [whole word] \\
\hline & Grassroot \\
\hline & Disab* \\
\hline \multicolumn{2}{|l|}{ DEVELOPMENT MECHANISMS } \\
\hline \multirow[t]{5}{*}{ Informatics } & ICT [specific term] \\
\hline & Information \\
\hline & Digital \\
\hline & Data \\
\hline & Mobile \\
\hline \multirow[t]{3}{*}{ Technovation } & Scien* \\
\hline & Technol* \\
\hline & Innovati* \\
\hline \multirow[t]{3}{*}{ Traditional Development Finance } & Aid [whole word] \\
\hline & ODA \\
\hline & Donor \\
\hline \multirow[t]{3}{*}{ New Development Finance } & Tax \\
\hline & Remittance \\
\hline & Philanthrop* \\
\hline New Stakeholders & Business \\
\hline
\end{tabular}




\begin{tabular}{|l|l|}
\hline & Communit* \\
\hline & Stakehold* \\
\hline & Cooperation \\
\hline & Partnership \\
\hline & Collab* \\
\hline Development Projects & Particip* \\
\hline & Implementation \\
\hline & Delivery \\
\hline & Management \\
\hline & Process* \\
\hline \multicolumn{2}{|c|}{ Evaluat* } \\
\hline Development Strategy & Monitor \\
\hline & Strateg* \\
\hline & Law \\
\hline & Policy/Policies \\
\hline DEVELOPMENT PERSPECTIVES & \\
\hline Complex Adaptive Systems & Resilien* \\
\hline & Complex/Complic* \\
\hline & Agile \\
\hline & Uncertain \\
\hline & Volati** \\
\hline & System* \\
\hline & Connec* \\
\hline & Adapt* \\
\hline & Shock(s) [whole words] \\
\hline & Risk \\
\hline & \\
\hline &
\end{tabular}




\section{Appendix C: Differences Between Post-2015 and Current Development Informatics Research Text}

Two tables are shown here. The first - Table C1 - calculates comparative frequencies between development informatics and post-2015 documentation for a series of individual terms. The lower the number below zero, the more the term is under-represented in DI documentation compared to post-2015 documentation. The higher the number above zero, the more it is over-represented. Some of these terms are stand-alone, and some are used as the basis (see Appendix B) for aggregated issues, which are shown in the second table; Table C2.

In both tables, as in Figure 2, the statistic shown is created in the following manner:

- ' $A$ ' represents the absolute difference in frequency of occurrences per 10,000 words, subtracting the PTDA figure from the DI figure.

- ' $R$ ' represents the relative difference for these statistics: dividing the absolute difference by the PTDA figure.

- The standard deviation of $A$ and $R$ is calculated for all data shown (a somewhat roughand-ready calculation given the data is unlikely to be normally distributed): SA and SR.

- The measure shown is calculated as the average deviation of each entry: ((A/SA) + $(\mathrm{R} / \mathrm{SR})) / 2$.

\begin{tabular}{|l|c|}
\hline Individual Development Issue & $\begin{array}{c}\text { Difference of DI } \\
\text { Research from } \\
\text { PTDA }\end{array}$ \\
\hline Sustainab* & -5.0 \\
\hline Partnership & -2.0 \\
\hline Environment* & -1.9 \\
\hline Finan* & -1.7 \\
\hline Poverty & -1.7 \\
\hline Economic & -1.3 \\
\hline Energy & -1.3 \\
\hline Food & -1.3 \\
\hline Rights & -1.3 \\
\hline Policy/Policies & -1.2 \\
\hline Resource & -1.2 \\
\hline Inclusi* & -1.2 \\
\hline Cooperation & -1.2 \\
\hline Accountab* & -1.2 \\
\hline (In)equalit* & -1.1 \\
\hline Growth & -1.0 \\
\hline Water & -1.0 \\
\hline Trade & -1.0 \\
\hline Peace & -0.9 \\
\hline Climate Change & -0.9 \\
\hline Implementation & -0.9 \\
\hline Women & -0.9 \\
\hline
\end{tabular}




\begin{tabular}{|c|c|}
\hline Individual Development Issue & $\begin{array}{l}\text { Difference of DI } \\
\text { Research from } \\
\text { PTDA }\end{array}$ \\
\hline Security & -0.8 \\
\hline Job & -0.8 \\
\hline Disaster & -0.8 \\
\hline Waste & -0.8 \\
\hline Agric* & -0.8 \\
\hline Child & -0.8 \\
\hline Income & -0.8 \\
\hline Violen* & -0.8 \\
\hline Transform* & -0.8 \\
\hline Vulnerab* & -0.7 \\
\hline Private & -0.7 \\
\hline Investment & -0.7 \\
\hline Nutrition & -0.7 \\
\hline Debt & -0.7 \\
\hline Civil Society & -0.7 \\
\hline Sanitation & -0.7 \\
\hline State(s) [whole words] & -0.7 \\
\hline Resilien* & -0.7 \\
\hline Transparen* & -0.7 \\
\hline Aid [whole word] & -0.6 \\
\hline Gender & -0.6 \\
\hline Government & -0.6 \\
\hline Least developed & -0.6 \\
\hline Small island & -0.6 \\
\hline Justice & -0.6 \\
\hline Food Security & -0.6 \\
\hline Social Protection & -0.6 \\
\hline Carbon & -0.6 \\
\hline Livelihood & -0.6 \\
\hline Land [whole word] & -0.6 \\
\hline Hunger & -0.6 \\
\hline Girl & -0.6 \\
\hline ODA & -0.6 \\
\hline Conflict & -0.6 \\
\hline Education & -0.6 \\
\hline Monitor* & -0.6 \\
\hline Services & -0.6 \\
\hline Risk & -0.5 \\
\hline Landlocked & -0.5 \\
\hline Leaders* & -0.5 \\
\hline Fragil* & -0.5 \\
\hline Governance & -0.5 \\
\hline
\end{tabular}




\begin{tabular}{|c|c|}
\hline Individual Development Issue & $\begin{array}{l}\text { Difference of DI } \\
\text { Research from } \\
\text { PTDA }\end{array}$ \\
\hline Renewable & -0.5 \\
\hline Business & -0.5 \\
\hline Shock(s) [whole words] & -0.5 \\
\hline Diversity [whole word] & -0.5 \\
\hline Philanthrop* & -0.5 \\
\hline Institution & -0.5 \\
\hline Law & -0.5 \\
\hline Disab* & -0.5 \\
\hline City/Cities [whole words] & -0.5 \\
\hline Tax & -0.5 \\
\hline Minorit* & -0.5 \\
\hline Volatil* & -0.5 \\
\hline Stakehold* & -0.5 \\
\hline Crisis/Crises & -0.5 \\
\hline Energy Security & -0.4 \\
\hline Mortality & -0.4 \\
\hline Urban & -0.4 \\
\hline Population & -0.4 \\
\hline Social Justice & -0.4 \\
\hline Malaria & -0.4 \\
\hline Well-being/Wellbeing & -0.4 \\
\hline Remittance & -0.4 \\
\hline Migra* & -0.4 \\
\hline Drug & -0.4 \\
\hline Productivity & -0.3 \\
\hline Free* & -0.3 \\
\hline Youth & -0.3 \\
\hline Market & -0.3 \\
\hline Employ* & -0.3 \\
\hline Regulat* & -0.3 \\
\hline Exclusion/Excluded & -0.3 \\
\hline Adapt* & -0.3 \\
\hline Innovati* & -0.3 \\
\hline Emerging & -0.3 \\
\hline System* & -0.3 \\
\hline Donor & -0.3 \\
\hline Strateg* & -0.3 \\
\hline Public & -0.2 \\
\hline Corrup* & -0.2 \\
\hline Uncertain & -0.2 \\
\hline Open [not Copenhagen] & -0.2 \\
\hline Commodit* & -0.2 \\
\hline
\end{tabular}




\begin{tabular}{|c|c|}
\hline Individual Development Issue & $\begin{array}{l}\text { Difference of DI } \\
\text { Research from } \\
\text { PTDA }\end{array}$ \\
\hline Management & -0.2 \\
\hline Grassroot & -0.2 \\
\hline Impact & -0.2 \\
\hline Bank* & -0.1 \\
\hline Money & -0.1 \\
\hline Faith & -0.1 \\
\hline Hope & -0.1 \\
\hline Politic* & -0.1 \\
\hline Maternal & -0.1 \\
\hline Oil [whole word] & -0.1 \\
\hline Terror* & -0.1 \\
\hline Process* & -0.1 \\
\hline Infrastructur* & -0.1 \\
\hline Militar* & 0.0 \\
\hline Skill & 0.0 \\
\hline Scien* & 0.0 \\
\hline Local & 0.0 \\
\hline Geograph* & 0.0 \\
\hline Manufactur* & 0.1 \\
\hline Religi* & 0.1 \\
\hline HIV/AIDS & 0.3 \\
\hline Rural & 0.3 \\
\hline Collab* & 0.3 \\
\hline Particip* & 0.3 \\
\hline Woman & 0.4 \\
\hline War(s) [whole words] & 0.4 \\
\hline Communit* & 0.4 \\
\hline Delivery & 0.4 \\
\hline Competit* & 0.5 \\
\hline Social & 0.5 \\
\hline Citizen & 0.5 \\
\hline Enterprise & 0.6 \\
\hline Humanitarian & 0.6 \\
\hline Moral [not morale] & 0.6 \\
\hline Complex/Complic* & 0.7 \\
\hline Entrepreneur & 0.7 \\
\hline Health & 0.7 \\
\hline Learning & 0.8 \\
\hline Culture [whole word] & 0.9 \\
\hline Capabilit* & 1.5 \\
\hline Technol* & 1.5 \\
\hline Non-government/NGO & 1.5 \\
\hline
\end{tabular}




\begin{tabular}{|l|c|}
\hline Individual Development Issue & $\begin{array}{c}\text { Difference of DI } \\
\text { Research from } \\
\text { PTDA }\end{array}$ \\
\hline Female & 1.6 \\
\hline Evaluat* & 2.0 \\
\hline Emotion & 2.2 \\
\hline Ethic* & 3.4 \\
\hline
\end{tabular}

Table C1: Development Informatics Research Gap Measure for Individual Terms

Note that Table C1 excludes terms related to informatics which are all inherently overrepresented in development informatics research compared to PTDA documentation. It also excludes terms not present in the PTDA documentation since they would return null values for percentage change (these are: commerce, weapon, nuclear, psychol*, happy/happiness, corporate social, agile and chao*). It also excludes universit* since that was massively over-represented in DI papers due to authors' organisational affiliations being included. 


\begin{tabular}{|l|c|}
\hline $\begin{array}{l}\text { Aggregated Development } \\
\text { Issue }\end{array}$ & $\begin{array}{c}\text { Difference of DI } \\
\text { Research from } \\
\text { PTDA }\end{array}$ \\
\hline $\begin{array}{l}\text { Environment and } \\
\text { Sustainability }\end{array}$ & -2.3 \\
\hline MDGs 1-6 & -0.9 \\
\hline Inclusive Development & -0.8 \\
\hline MDG 8 & -0.8 \\
\hline New Stakeholders & -0.7 \\
\hline Insecurity & -0.7 \\
\hline Rights and Justice & -0.7 \\
\hline Open Development & -0.6 \\
\hline Development Strategy & -0.6 \\
\hline Growth and Jobs & -0.5 \\
\hline Traditional Development & -0.5 \\
\hline Finance & -0.4 \\
\hline New Development Finance & -0.4 \\
\hline Urban Development & -0.3 \\
\hline Institutional Development & -0.3 \\
\hline Development Projects & -0.3 \\
\hline Services & -0.3 \\
\hline Livelihoods & -0.3 \\
\hline Complex Adaptive Systems & -0.2 \\
\hline Rural/Agricultural & -0.2 \\
\hline Development & 0.0 \\
\hline Migra* & 0.0 \\
\hline Infrastructur* & 0.1 \\
\hline Wellbeing & 0.4 \\
\hline Manufactur* & 3.6 \\
\hline Technovation & \\
\hline Informatics & \\
\hline & \\
\hline
\end{tabular}

Table C2: Development Informatics Research Gap Measure for Aggregated Issues 
Appendix D: Development Informatics Journal Start Dates

\begin{tabular}{|l|c|c|}
\hline Journal Title & $\begin{array}{c}\text { Start } \\
\text { Year }\end{array}$ & $\begin{array}{c}\text { DI Research } \\
\text { Wave }\end{array}$ \\
\hline Information Development & 1985 & Two \\
\hline Information Technology for Development & 1986 & Two \\
\hline Asian Journal of Communication & 1990 & Two \\
\hline South African Journal of Information Management & 1999 & Three \\
\hline Electronic Journal of Information Systems in Developing Countries & 2000 & Three \\
\hline African Journal of Information and Communication & 2000 & Three \\
\hline Asian Journal of Information Technology & 2002 & Three \\
\hline Information Technologies and International Development & 2003 & Three \\
\hline $\begin{array}{l}\text { International Journal of Education and Development Using Information and } \\
\text { Communication Technology }\end{array}$ & 2005 & Three \\
\hline African Journal of Information \& Communication Technology & 2005 & Three \\
\hline Journal of Health Informatics in Developing Countries & 2007 & Four \\
\hline Asian Journal of Information Management & 2007 & Four \\
\hline International Journal on Advances in ICT for Emerging Regions & 2008 & Four \\
\hline African Journal of Information Systems & 2008 & Four \\
\hline $\begin{array}{l}\text { International Journal of Information Communication Technologies and } \\
\text { Human Development }\end{array}$ & 2009 & Four \\
\hline International Journal of ICT Research and Development in Africa & 2010 & Four \\
\hline
\end{tabular}

